\title{
A legitimidade democrática da jurisdição constitucional e o contramajoritarismo no contexto da judicialização da política e do ativismo judicial
}

Logan Caldas Barcellos ${ }^{1}$

\section{Resumo}

O presente trabalho aborda a legitimidade democrática da jurisdição constitucional contramajoritária, tomando como paradigma o pensamento de Dworkin acerca da democracia constitucional. Busca enfrentar os temas da judicialização da política e do ativismo judicial e debater acerca da intervenção do Poder Judiciário no cenário político, trazendo os argumentos favoráveis e contrários à sua atuação. Para tanto, questiona os limites e possibilidades da jurisdição constitucional a partir do contramajoritarismo e do respeito aos direitos fundamentais. Como método de abordagem utilizar-se-ão os métodos dedutivo e indutivo. Como método de procedimento, os métodos histórico e monográfico, e como técnicas de pesquisa será utilizada a documentação direta, ou seja, a jurisprudência, e indireta, a pesquisa bibliográfica.

Palavras-chave: Legitimidade democrática. Jurisdição constitucional. Judicialização da política. Ativismo judicial.

\section{Introdução}

O trabalho aborda a legitimidade democrática da jurisdição constitucional contramajoritária diante de dois fenômenos: a judicialização da política e das relações sociais e o ativismo judicial. Trata-se de debater acerca da intervenção da Justiça constitucional, questionando os limites da sua atuação, a partir da noção de democracia constitucional em Dworkin.

1 Advogado. Mestre em Direito Público pela Unisinos, RS. Especialista em direito previdenciário pela Faculdade IDC, RS. Graduado em Direito pela Unisinos, RS. 
Intenta-se explanar a inexorabilidade da atuação da Justiça constitucional em temas de grande interesse político. O ativismo judicial será abordado a partir de breve análise de algumas decisões de Tribunais brasileiros, especialmente o Supremo Tribunal Federal e o Tribunal Superior Eleitoral.

A divisão da temática busca atingir os seguintes objetivos:

a) expor as causas e o significado da judicialização da política e das relações sociais no Brasil;

b) debater acerca de algumas decisões do Supremo Tribunal Federal e do Tribunal Superior Eleitoral que foram taxadas de ativistas por setores da doutrina; e

c) analisar se a intervenção cada vez maior da jurisdição constitucional pode significar um atentado à democracia a partir da democracia constitucional de Dworkin

A partir da democracia constitucional de Dworkin, é possível refutar muitas críticas efetuadas contra a atuação mais incisiva da jurisdição constitucional pelos defensores do majoritarismo (ou da prevalência da vontade da maioria), entre os quais se pode incluir Jeremy Waldron.

Em suma, cumpre lembrar as críticas que a Justiça constitucional tem sofrido e trazer elementos que possibilitem o debate acerca dos riscos e vantagens da jurisdição constitucional. É preciso destacar a função de garantia da jurisdição e o problema da crise de representatividade política. Além disso, considerar as peculiaridades da situação brasileira, como a existência de omissões inconstitucionais e as possibilidades hermenêuticas de superação da crise política, buscando argumentos de legitimação democrática da jurisdição constitucional no Estado Democrático de Direito.

\section{As origens da jurisdição Constitucional}

Não se pode compreender o que significa a jurisdição constitucional sem remontar às suas origens, da mesma forma como é impossível conhecer um rio 
sem ir às suas nascentes. ${ }^{2}$ Suas origens mais remotas estão no próprio desenvolvimento e nascimento do Constitucionalismo. Conforme leciona Canotilho, ${ }^{3}$ em termos rigorosos, não há um único constitucionalismo, mas vários constitucionalismos, como o americano, francês, brasileiro, português etc. Cada um desses países teve seus movimentos constitucionais próprios, diacrônicos, em espaços geográficos distintos e sob a influência de diferentes culturas. Os diversos constitucionalismos podem ser mais bem denominados de movimentos constitucionais. Isso não quer dizer que não haja um intercâmbio cultural entre os países, que concepções consagradas em um não venham a influenciar outro; de fato, apesar de cada movimento constitucional ser próprio e autônomo, ao mesmo tempo sofre a injunção das forças políticas nacionais e internacionais, conquanto a nação preserve a sua soberania. A expressão “Constitucionalismo”, segundo Canotilho:

2 Em Hegel a jurisdição é forma de administração da justiça. A jurisdição deve ser considerada tanto um dever como um direito do poder público. Na pena aplicada por um crime cometido, há uma reconciliação do direito consigo mesmo e com a lei por parte do criminoso. $\mathrm{Na}$ aplicação da lei, o criminoso se sujeita à satisfação da justiça, a uma ação que é sua. O membro da sociedade civil tem o direito de assistir ao julgamento, de se apresentar ao Tribunal e só perante ele reivindicar o reconhecimento de um direito contestado. $\mathrm{O}$ direito deve ser demonstrado através dos meios de provas cabíveis e pelos procedimentos previstos. O Tribunal, ciente de que o formalismo processual poderá prejudicar as partes, deverá buscar o acordo. A equidade significa que, por razões de moralidade, se rompeu com o direito formal, considerando a natureza do caso particular. As deliberações dos membros do Tribunal ainda são expressões de opiniões subjetivas, e não são, portanto, algo público. Há o necessário reconhecimento do caso particular e a absorção do caso na lei que restabelece o direito. $\mathrm{Na}$ organização jurídica romana, esta diferença de funções manifestava-se no fato de o pretor produzir sua decisão quando as coisas se passavam de determinada maneira e encarregar um juiz especial de inquirir sobre a natureza do caso. No direito inglês, a determinação da ação segundo a qualidade criminal definida (se é, por exemplo, um homicídio involuntário ou um assassínio), pertence ao livre-arbítrio do queixoso. Cumpre, sobretudo, ao juiz qualificado a condução da totalidade do processo. A prova não contém uma determinação objetiva absoluta e o que na decisão soberanamente prevalece é a convicção subjetiva, a certeza de consciência (animi sententia). Demonstrar uma determinação racional como o conceito de Direito exige um método que não é o da demonstração de um teorema geométrico. No conteúdo empírico que é um fato, importa a intuição sensível dada, a certeza sensível subjetiva, as declarações e testemunhos. A sentença, que é a qualificação de um caso sob o aspecto legal, assegura o direito subjetivo das partes. O direito da consciência é satisfeito pela confiança na subjetividade de quem decide. Cf. HEGEL, Georg Friedrich Wilhelm. Princípios da filosofia do direito. São Paulo: M. Fontes, 1997.

3 CANOTILHO, José Joaquim Gomes. Direito constitucional e teoria da Constituição. 4. ed. Coimbra: Almedina, 1998. p. 51. 
Éa teoria ou ideologia que ergue o princípio do governo limitado indispensável à garantia dos direitos em dimensão estruturante da organização político-social de uma comunidade. Nesse sentido, o constitucionalismo moderno representará uma técnica de limitação do poder com fins garantísticos. O conceito de constitucionalismo transporta, assim, um claro juízo de valor. É, no fundo, uma teoria normativa da política, tal como a teoria da democracia ou a teoria do liberalismo. ${ }^{4}$

O constitucionalismo moderno é, em uma acepção histórico-descritiva, um movimento político, social e cultural que, a partir do séc. XVIII, questiona o domínio político tradicional, opondo-se ao constitucionalismo antigo, que era calcado em princípios escritos e no direito consuetudinário, em direitos estamentais e era rico em privilégios políticos. ${ }^{5}$ Pode-se dizer que é o constitucionalismo moderno - que aos poucos vai substituindo a noção de que a Lei estava nos Códigos, pois a Lei passa a ser substancialmente a Constituição - uma das grandes conquistas da Humanidade, pois visa preservar o homem do arbítrio, garantindo-lhe direitos contra o soberano.

Sabe-se que as origens do controle difuso de constitucionalidade estão nos USA, particularmente na decisão do juiz Marshall, em 1803, no caso Marbury vs. Madison, cuja temática versava sobre os procedimentos para a nomeação de juízes. William Marbury ingressou judicialmente pleiteando sua nomeação. Nesse caso, Marshall considerou dever da Corte julgar de acordo com a Constituição. É claro que a decisão de Marshall consubstanciou o grande locus teórico de afirmação do controle difuso, mas não foi isolada, pois antes mesmo dessa data o juiz Coke defendia a supremacia da lei (rule of Law) e o controle do poder. A jurisprudência da Suprema Corte assimilou gradualmente os efeitos benéficos e “educativos" da decisão notável do juiz Marshall, pois no caso Fletcher vs. Peck, em 1810, considerou que as legislações estaduais deveriam ser submetidas à supremacia da Constituição, assim como em 1816, no caso Martin vs. Hunters considerou a supremacia da Suprema Corte sobre as Cortes Estaduais. ${ }^{6}$

${ }^{4}$ CANOTILHO, José Joaquim Gomes. Direito constitucional e teoria da Constituição. 4. ed. Coimbra: Almedina, 1998. p. 51.

5 CANOTILHO, José Joaquim Gomes. Direito constitucional e teoria da Constituição. 4. ed. Coimbra: Almedina, 1998. p. 52.

${ }^{6}$ OHLWEILER, Leonel Pires. O contributo da jurisdição constitucional para a formação do regime jurídico administrativo. Revista do Instituto de Hermenêutica Jurídica: (Neo) Constitucionalismo: ontem os códigos, hoje as constituições, Porto Alegre, v.1, n. 2, p. 295, 2004. 
Entretanto, o grande precursor do controle de constitucionalidade advém da matriz inglesa: Sir Edward Coke (1552-1634). É preciso aclamar as decisões de Coke, não somente pelo "peso" que tiveram em termos de influência histórica, inclusive em Marshall, mas por ter efetivamente compreendido o "que é ser um juiz", ou seja, que o poder judicial deve defender a Constituição. Assim é que Coke invocava o direito da Commom Law $^{7}$ contra as pretensões absolutistas do Stuart. Coke é uma espécie de juiz que enxergava além de seu tempo, pois em pleno séc. XVII ele entreviu a possibilidade de controle judicial de constitucionalidade, quase dois séculos antes de Marshall, e em plena era de supremacia do Parlamento na Inglaterra (adite-se que mesmo após a célebre decisão de Marshall em 1803 foi necessário um longo tempo de "digestão" para os magistrados americanos entreverem a importância do controle difuso de constitucionalidade). ${ }^{8}$

7 A respeito dos períodos do direito inglês, cf. STRECK, Lenio Luiz; MORAIS, José Luis Bolzan de. Jurisdição constitucional e hermenêutica. 2. ed. Rio de Janeiro: Forense, 2004. p. 291. Fica bem claro em John Gilissen a diferença central entre a Commom Law e a Civil Law. Enquanto a primeira se baseia em Statutes (Statutes are the Law), na segunda judge-made-law. A Commom Law surge historicamente no séc. XII. Pode-se dizer que a Commom Law tem um longo e milenar período de maduração, diferentemente da Civil Law, cujos efeitos passaram a ser sentidos na Revolução Francesa e hoje completa aproximadamente dois séculos. A expressão Commom Law é utilizada desde o séc. XIII para designar o direito comum inglês, porém seu sentido é diferente do ius commune, designado para se referir ao direito erudito baseado no direito romano no séc. XVI. A Commom Law é um direito jurisprudencial criado pelos juízes reais e baseado em precedentes. Isto não quer dizer que hodiernamente (séc. XX e XXI) a Civil Law não tenha ganhado certo espaço no seio da Commom Law, pois o statute Law tem ganhado um peso cada vez maior. Diz Gilissen: "O direito inglês moderno é por conseqüência muito mais histórico que os direitos dos países da Europa Continental; não houve ruptura entre o passado e o presente, como a que a Revolução de 1789 provocou em França e noutros países. Os juristas ingleses do século XX invocam ainda leis e decisões judiciárias dos séculos XIII e XIV”. Cf. GILISSEN, John. Introdução histórica ao direito. 4. ed. Lisboa: Fundação Calouste Gulbenkian, [2007?]. p. 208. Diz René David que o direito inglês é baseado em case Law, suas regras são as que se encontram na ratio decidendi das decisões dos Tribunais Superiores da Inglaterra. A lei é secundária e só será aplicada na medida em que o façam os Tribunais. DAVID, René. Os grandes sistemas do direito contemporâneo. São Paulo: M. Fontes, 2000. p. 433.

8 STRECK, Lenio Luiz; MORAIS, José Luis Bolzan de. Jurisdição constitucional e hermenêutica. 2. ed. Rio de Janeiro: Forense, 2004. p. 335. 
Foram fundamentais as sentenças sobre os writs of prohibition, as Proclamations (ordenanças administrativas) e o processo Bonham. ${ }^{9}$ Na primeira, Coke afirmou diante do rei a Commom Law face à Sagrada Escritura, negando que o rei Jaime I avocasse certos feitos para julgá-los. Na segunda, afirmou que o rei não podia violar uma lei mediante ordenações, pois não eram fontes do direito inglês e somente o Parlamento podia fazer statutes. Mas é no caso Bonham que se credita a Coke a moderna instituição do controle de constitucionalidade de leis pelo Poder Judiciário. ${ }^{10}$ Coke defendeu o controle dos atos do Parlamento: se o ato deste último é contrário à Commom Law, deverá ser declarado judicialmente nulo, ou seja, existe um direito superior ao do Parlamento, cujos guardiões devem ser os juízes da Commom Law. Apesar disso, a partir de 1688, vinga na Inglaterra a supremacia do Parlamento, e atualmente não se pode falar em controle de constitucionalidade na Inglaterra, pois quem decide em última instância é o Parlamento. ${ }^{11}$ Diz Streck:

[...] a doutrina cunhada por Edward Coke foi exportada para os Estados Unidos, o que pode se ver em muitas sentenças anteriores à Constituição de 1787. Com efeito, os colonos encontram em Coke e em Locke seus mentores jurídicos diretos. Ambos são herdeiros da grande tradição jusnaturalista européia, na medida em que expressamente apóiam sua concepção de um parâmetro normativo superior às leis positivas: o Direito Natural, que é a expressão de uma lex eterna e lex legum, Lei para todas as leis. O Bonham's case de 1610 recorda expressamente esses dois caracteres: even in Act of Parliement made against Natural equity is void in itself; for "iura naturae sunt immutabilia" and they are "leges legum"."

Paradoxalmente, em que pese à supremacia do Parlamento na Inglaterra, ela é a precursora do controle de constitucionalidade por meio de Coke, influenciando a matriz americana, terra do controle difuso. Quanto ao controle concentrado

9 STRECK, Lenio Luiz; MORAIS, José Luis Bolzan de. Jurisdição constitucional e hermenêutica. 2. ed. Rio de Janeiro: Forense, 2004. p. 305.

${ }^{10}$ STRECK, Lenio Luiz; MORAIS, José Luis Bolzan de. Jurisdição constitucional e hermenêutica. 2. ed. Rio de Janeiro: Forense, 2004. p. 306.

${ }^{11}$ STRECK, Lenio Luiz; MORAIS, José Luis Bolzan de. Jurisdição constitucional e hermenêutica. 2. ed. Rio de Janeiro: Forense, 2004. p. 307.

${ }^{12}$ STRECK, Lenio Luiz; MORAIS, José Luis Bolzan de. Jurisdição constitucional e hermenêutica. 2. ed. Rio de Janeiro: Forense, 2004. p. 334. 
de constitucionalidade, seu pai é Kelsen, idealizador do Tribunal Constitucional Austríaco e do controle de constitucionalidade. Ressalte-se que o Tribunal Constitucional Austríaco não exerce funções propriamente jurisdicionais, porquanto não é um órgão jurisdicional, mas legislativo, pois sua função é exclusivamente avaliar a compatibilidade em abstrato das normas, ou seja, não é uma instância recursal do Poder Judiciário, como é o caso do Supremo Tribunal Federal, no Brasil, mas limita-se exclusivamente ao controle concentrado. ${ }^{13}$ Favoreu $^{14}$ indica que entre as principais Cortes Constitucionais europeias, incluindo as da Alemanha, Itália, França, Espanha, Portugal e Bélgica, a Corte Austríaca serviu de modelo basilar na implementação do controle concentrado de constitucionalidade. Surgiu em 1920 e é a mais antiga da Europa.

Tornou-se célebre o debate entre Schmitt e Kelsen. Pode-se expor sinteticamente o fato de Schmitt ${ }^{15}$ considerar o Presidente do Reich como Guardião da Constituição, e não qualquer órgão do Poder Judiciário. As críticas de Schmitt ao Judiciário são amplas, pois ele considera que um juiz independente é aquele que não abandona a subsunção e a vinculação material à lei, ou seja, ele tem receio dos perigos decorrentes da criatividade judicial. ${ }^{16}$ Schmitt considera o juiz vinculado à letra da lei. ${ }^{17}$

Da obra de Schmitt, podem-se tomar algumas conclusões: a) Schmitt considera que o pluralismo tornou o Parlamento incapaz de obter unidade e conseguir determinar os rumos da nação; b) os juízes, na medida em que passam a trabalhar com cláusulas gerais ou conceitos indeterminados, assumem funções políticas incompatíveis com a magistratura, perdendo sua independência, pois a politização

${ }^{13}$ STRECK, Lenio Luiz; MORAIS, José Luis Bolzan de. Jurisdição constitucional e hermenêutica. 2. ed. Rio de Janeiro: Forense, 2004. p. 297.

${ }^{14}$ FAVOREU, Louis. As cortes constitucionais. São Paulo: Landy, 2004. p. 48.

${ }^{15}$ SCHMITT, Carl. O guardião da Constituição. Belo Horizonte: Del Rey, 2007. p. 229.

${ }^{16}$ SCHMITT, Carl. O guardião da Constituição. Belo Horizonte: Del Rey, 2007. p. 229.

${ }^{17}$ Ao invés de realçar a importância dos princípios na interpretação judicial, Schmitt vê como um perigo os juízes lidarem com cláusulas gerais. A respeito do pós-positivismo, cf. a obra de BONAVIDES, Paulo. Curso de direito constitucional. 19. ed. São Paulo: Malheiros, 2006. p. 264. 
da justiça é prejudicial a esta. ${ }^{18} \mathrm{O}$ Judiciário é incapaz de suprir as insuficiências do Poder Legislativo, pois só age post factum. ${ }^{19} \mathrm{Schmitt}$ considera que os juízes não podem querer resolver certos problemas políticos, pois o Judiciário carece de estrutura para tanto, e não pode sintetizar o espírito do povo em suas sentenças. Daí porque somente o Presidente do Reich pode formar a "unidade nacional".

Kelsen refuta tais argumentos, considerando que a teoria do poder neutro, que Schmitt invoca de Benjamin Constant, é uma relíquia do constitucionalismo, uma doutrina ideológica, que, sob o pretexto de neutralizar os conflitos entre os Poderes, no fundo serve de justificação do poder quase absoluto do chefe de Estado. ${ }^{20}$ Trata-se de uma ficção de notável acuidade, feita para os que acreditam que o monarca, em que pese ao seu poder imensurável, poderia ser efetivamente um poder neutro. Na prática, denuncia Kelsen, tal "neutralidade" nada mais é do que um argumento político extremamente tendencioso.

O poder que Schmitt concede ao Presidente do Reich é tamanho, que não seria irrazoável dizer que ele constitui uma Ditadura, visto que Schmitt não a chame assim. De fato, em Schmitt o Presidente do Reich está acima da lei, porque ele governa acima de qualquer limite, ${ }^{21}$ sob o pressuposto de que somente ele pode materializar o espírito do povo e constituir a unidade da nação. Schmitt ainda está preso à velha tese que o juiz deve tão somente subsumir o conteúdo da lei no caso concreto, como se a jurisdição fosse um automatismo jurídico, (relembrando a Escola da Exegese e o juiz "boca da lei" de Montesquieu). ${ }^{22}$ Kelsen acusa Schmitt de não ter notado a experiência do Tribunal Constitucional Austríaco nas suas divagações, pois deixou de avaliar os tribunais "em concreto". ${ }^{23}$ Schmitt não admite a tese kelseniana de que os juízes são guardiães da Constituição, pois é preciso um órgão político para realizar esta tarefa. As cortes ordinárias não podem ser

\footnotetext{
${ }^{18}$ SCHMITT, Carl. O guardião da Constituição. Belo Horizonte: Del Rey, 2007. p. 33.

${ }^{19}$ SCHMITT, Carl. O guardião da Constituição. Belo Horizonte: Del Rey, 2007. p. 47.

${ }^{20}$ KELSEN, Hans. Jurisdição constitucional. São Paulo: M. Fontes, 2003. p. 240.

${ }^{21}$ BIGNOTTO, Newton. Soberania e exceção no pensamento de Carl Schmitt. Kriterion, Belo Horizonte, n. 118, p. 401-415, dez. 2008.

${ }^{22}$ KELSEN, Hans. Jurisdição constitucional. São Paulo: M. Fontes, 2003. p. 258.

${ }^{23}$ KELSEN, Hans. Jurisdição constitucional. São Paulo: M. Fontes, 2003. p. 285.
} 
guardiãs, já que elas são desconectadas do "campo gravitacional" da política. ${ }^{24} \mathrm{~A}$ Corte deve simplesmente aplicar a lei, ela não pode ter autonomia para extrapolar seu âmbito burocrático e decidir acerca do que é ou não imperioso ao Estado. Sua função não pode ser tão proeminente assim, e nem política, sob pena de perder sua neutralidade e independência.

\section{A judicialização da política e das relações sociais}

A judicialização da política e das relações sociais no Brasil é um fenômeno que pode ser considerado recente, entrevendo o fato de a Constituição de 1988 ter dado ao Poder Judiciário um papel proeminente na consolidação da democracia e na concretização de direitos fundamentais, inclusive mediante instrumentos processuais específicos ${ }^{25}$. Barroso ${ }^{26}$ chama de "judicialização da vida” esse fenômeno, porque de fato o Judiciário penetrou na vida das camadas sociais, inclusive nas mais baixas, por meio da instituição dos Juizados Especiais.

Judicialização significa que algumas questões de larga repercussão política ou social estão sendo decididas por órgãos do Poder Judiciário, e não pelas instâncias políticas tradicionais: o Congresso Nacional e o Poder Executivo em cujo âmbito se encontram o Presidente de República, seus ministérios e a administração pública em geral. Como intuitivo, a judicialização envolve uma transferência de poder para juízes e tribunais, com alterações significativas na linguagem, na argumentação e no modo de participação da sociedade $[\ldots] .^{27}$

${ }^{24}$ BOCKENFORDE, Ernst-Wolfang. The concept of the political: a key to understanding Carl Schmitt's Constitucional Theory. In: DYZENHAUS, David (Org.). Law as politics: Carl Schmitt critique of liberalism. Durham: Duke University, 1998. p. 45.

${ }^{25}$ Garantias constitucionais como habeas corpus, habeas data, mandado de segurança, mandado de injunção, ação civil pública e a ação popular desempenham uma importante função na redemocratização do país, demonstrando o comprometimento do Estado na superação do regime militar, através da tutela de direitos e liberdades fundamentais que haviam sido cassadas pelo Ato Institucional n. 5.

${ }^{26}$ BARROSO, Luís Roberto. Judicialização, ativismo judicial e legitimidade democrática. Revista Direito do Estado, Salvador, ano 4, n. 13, p. 71-91, jan./mar. 2009.

${ }^{27}$ BARROSO, Luís Roberto. Judicialização, ativismo judicial e legitimidade democrática. Revista Direito do Estado, Salvador, ano 4, n. 13, p. 73, jan./mar. 2009. 
As causas da judicialização da política são, segundo o autor:

a) redemocratização do país, especialmente a partir da Constituição de 1988, pois a recuperação das garantias da magistratura fez com que o Judiciário deixasse de ser um departamento técnicoespecializado para se tornar um verdadeiro poder político, capaz de fazer valer a Constituição inclusive contra outros Poderes. Além disso, o Ministério Público, que nasceu criminal, passou a atuar em outras demandas, e a Defensoria Pública foi fortalecida;

b) constitucionalização abrangente, que trouxe para a constituição diversas matérias que eram excluídas do texto constitucional (constituição analítica);

c) o sistema brasileiro de controle de constitucionalidade, que é eclético ou híbrido, posto que combina os modelos de controle difuso e concentrado.

O Supremo Tribunal Federal atua como corte recursal nos recursos extraordinários e faz às vezes de "tribunal constitucional" quando avalia a compatibilidade em abstrato de normas com a Constituição ${ }^{28}$. É importante ressaltar, a partir do que concluiu o autor, que a judicialização não pode ser imputada aos Ministros do Supremo Tribunal Federal ou aos juízes, como se fosse uma pretensão de um modelo juriscêntrico de hegemonia judicial, porque ela implica em um cumprimento da Constituição. A atuação dos juízes em certas questões políticas decorre da própria exigência do texto constitucional e não são caprichos do Judiciário ou opções ideológicas. ${ }^{29}$

Carvalho $^{30}$ afirma que a judicialização da política pode ser vista por um prisma normativo ou um prisma analítico. Em um prisma normativo, avalia a supremacia da Constituição sobre decisões parlamentares majoritárias, desaguando

${ }^{28}$ BARROSO, Luís Roberto. Judicialização, ativismo judicial e legitimidade democrática. Revista Direito do Estado, Salvador, ano 4, n. 13, p. 74, jan./mar. 2009.

${ }^{29}$ BARROSO, Luís Roberto. Judicialização, ativismo judicial e legitimidade democrática. Revista Direito do Estado, Salvador, ano 4, n. 13, p. 75, jan./mar. 2009.

${ }^{30}$ CARVALHO, Ernani Rodrigues de. Em busca da judicialização da política no Brasil: apontamentos para uma nova abordagem. Revista de Sociologia Política, Curitiba, n. 23, p. 115-126, nov. 2004. 
no debate entre substancialistas e procedimentalistas. ${ }^{31}$ Em uma visão analítica, preocupa-se com o ambiente político e institucional. Pode-se citar como exemplo de um trabalho analítico o de Vianna, expondo o contexto democrático da judicialização da política e das relações sociais no Brasil. ${ }^{32}$

Uma obra relevante quanto à judicialização da política é a de Vallinder, T. e Tate, C. Neal. ${ }^{33}$ Vallinder considera que existem dois tipos de judicialização: a) from without, que é a reação do Judiciário a um terceiro, consubstanciando uma revisão de sua decisão, especialmente no controle de constitucionalidade; b) from within, ou seja, a incorporação dos métodos e procedimentos dos juízes pelas instituições como os Poderes Executivo e Legislativo (contenciosos tributários e CPIs). O trabalho publicado em 1995, The Global expansion of judicial power, foi o primeiro a cunhar o termo "judicialização da política" no vocabulário da ciência política contemporânea. ${ }^{34} \mathrm{~A}$ judicialização pode ser considerada como policy-seeking approach e unconstrained courts approach. Na primeira, implica em um controle do Judiciário sobre as políticas da maioria. Na segunda, assevera-se que o Tribunal,

${ }^{31} \mathrm{O}$ debate entre substancialistas e procedimentalistas é tratado por Werneck Vianna et al. Segundo o eixo procedimentalista, composto por autores como Habermas e Garapon, o Judiciário tem a função de assegurar os procedimentos democráticos, visando à formação do processo de vontade majoritária. O eixo substancialista, com autores como Mauro Cappelletti e Dworkin, advoga uma postura mais ativa da jurisdição. Habermas somente admite uma jurisdição constitucional mais "ofensiva" quando se trata da imposição do procedimento democrático. Tanto Dworkin como Cappelletti desconfiam do Poder Legislativo. O eixo substancialista valoriza o ativismo judicial a respeito, cf. VIANNA, Luiz Werneck et al. A judicialização da política e das relações sociais no Brasil. Rio de Janeiro: Revan, 1999. p. 33. De fato, tais autores sabem que o Legislativo nem sempre representa a vontade popular. Dworkin criou seu modelo ideal do "juiz Hércules" para representar o papel dos magistrados em uma democracia, especialmente seu viés representativo dos interesses de uma comunidade histórica. Habermas critica o "diálogo monológico" de Hércules como meio para se alcançar o âmago da cultura democrática de uma sociedade.

32 VIANNA, Luiz Werneck et al. A judicialização da política e das relações sociais no Brasil. Rio de Janeiro: Revan, 1999.

${ }^{33}$ VALLINDER, T; TATE, C. Neal. The global expansion of judicial power: the judicialization of politics. New York: New York University, 1995.

${ }^{34}$ CARVALHO, Ernani Rodrigues de. Judicialização da política no Brasil: controle de constitucionalidade e racionalidade política. Análise Social, v. 191, p. 315-335. 2009. 
dada sua independência, pode decidir sem qualquer constrangimento, pois não precisa agradar as maiorias parlamentares. ${ }^{35}$
A judicialização da política requer que os operadores da lei prefiram participar da policy-making a deixá-la ao critério de políticos e administradores, e, em sua dinâmica, ela própria implicaria papel político mais positivo da decisão judicial do que aquele envolvido em uma não-decisão. Daí que a idéia de judicialização envolve tanto a dimensão procedimental quanto substantiva do exercício das funções judiciais. ${ }^{36}$

As origens da judicialização da política e o consequente fortalecimento do Poder Judiciário no mundo estão ligados ao ocaso do comunismo no Leste Europeu e ao fim da União Soviética. Os EUA passaram a ter um papel proeminente não somente nos domínios do Capitalismo, mas também com o seu modelo de revisão judicial. Daí porque a Ásia, a América Latina e a África sofreram forte influência do modelo americano, que desempenhou um papel importante a Corte de Estrasburgo, após a II Guerra Mundial. ${ }^{37}$

Um exemplo de judicialização da política no Brasil ocorre nos âmbitos do direito à saúde e do direito à educação. Trata-se de problema político premente que cada vez mais se desloca ou transfere para o Poder Judiciário, que se torna "fiador" da dívida dos outros Poderes, originária do descumprimento dos deveres constitucionais. Em que pese a todas as críticas que os juízes sofrem por imporem condutas ao Poder Executivo (o que muitos chamam de "politização da justiça"), eles foram empossados para cumprir a Constituição e a judicialização do direito à saúde não é uma faculdade, mas sim um dever do Poder Judiciário. Daí porque autores como Sarlet ${ }^{38}$ sustentam que, em que pese aos limites fáticos (reserva do

\footnotetext{
${ }^{35}$ CARVALHO, Ernani Rodrigues de. Judicialização da política no Brasil: controle de constitucionalidade e racionalidade política. Análise Social, v. 191, p. 317. 2009.

${ }^{36}$ MACIEL, Débora; KOERNER, Andrei. Sentidos da judicialização da política: duas análises. In: Lua Nova. 2002, n. 57, p. 113-133. Disponível em: <http://www.scielo.br/pdf/ln/ n57/a06n57.pdf>. Acesso em: 16 nov. 2009.

${ }^{37}$ A respeito, cf. VALLINDER, T; TATE, C. Neal. The global expansion of judicial power: the judicialization of politics. New York: New York University, 1995.

38 SARLET, Ingo. Contornos do direito fundamental à saúde na Constituição Federal de 1988. Revista da Procuradoria-Geral do Estado do Rio Grande do Sul. Porto Alegre, v. 25, n. 56, p. 57, dez. 2002.
} 
possível) e jurídicos (reserva parlamentar em matéria orçamentária), não se pode impedir o reconhecimento pelos juízes de direitos subjetivos a prestações, pelo menos não em todas as hipóteses.

O controle judicial das políticas públicas é um claro exemplo de judicialização da política. Nesse âmbito de atuação judicial, o Judiciário se torna garantidor de políticas públicas. A legitimidade democrática da sua atuação, significando um reconhecimento das suas decisões pela comunidade, ${ }^{39}$ ocorre pelo descumprimento da Constituição por parte dos gestores públicos, não podendo a justiça se isentar das suas responsabilidades.

Como se pode observar na experiência forense, a reserva do possível e a limitação orçamentária se tornaram frequentemente "álibis teóricos" que visam tornar os gestores públicos isentos de suas responsabilidades institucionais, ou seja, proporcionam uma falta total de accountability. Não pode ser o Poder Judiciário sujeito às falácias e demagogias alegadas muitas vezes pelos entes públicos. É preciso comprovar nessas hipóteses em que são alegadas a reserva do possível e os limites orçamentários: a) que efetivamente há ausência de verbas, trazendo aos autos o orçamento do ente público, seu comprometimento nas políticas públicas e a destinação que lhe é dada; b) que não houve aplicação de recursos em políticas menos importantes, deixando interesses centrais da comunidade sem qualquer forma de guarida; c) que o gestor público tem tido comprometimento na solução dos problemas institucionais e está se empenhando para suprir as carências existentes.

O enfoque analítico dado por Vianna no âmbito da judicialização da política e das relações sociais se atém à democracia. Embora trate objetivamente da judicialização da política no texto, no fundo o autor elogia tal fenômeno, porque o considera fundamental para a consolidação da democracia no país após a ditadura militar. Mencionam os autores:

${ }^{39}$ DINIZ, Antônio Carlos. Legitimidade. In: BARRETO, Vicente de Paulo (Coord.). Dicionário de Filosofia do Direito. São Leopoldo: Unisinos; Rio de Janeiro: Renovar, 2006. p. 514-517. 
[...] O Judiciário, assim, não se substituiria à política, mas preencheria um vazio, que, nas sociedades de massas com intensa mobilização social (como a brasileira), poderia vir a conceder "consistência democrática a [um] excedente de soberania popular que escapa à expressão do sufrágio.

$\mathrm{Na}$ experiência brasileira, como se procurou apontar na Parte I, o que se chama judicialização da política não é o resultado de um protagonismo institucional exercido pelo Poder Judiciário. Ela deriva, diversamente, de novas práticas de resistência da sociedade civil, particularmente dos partidos que compõe a minoria parlamentar e das associações de interesses dos setores subalternos, que vêm encontrando na comunidade dos intérpretes um caminho para reforçar a sua representação. De igual modo, no que, aliás, reitera a experiência universal, a judicialização das relações sociais, investigada na Parte II, é mais expressão de demandas igualitárias por parte de uma sociedade que tem exercido a capacidade de incorporação do sistema político e da vida associativa em geral, do que um exercício de um papel salvífico por parte do Judiciário. (destaquei). ${ }^{40}$

A chamada judicialização das relações sociais tem base no direito comparado, ${ }^{41}$ especialmente nas experiências das Small Claims Courts. Nos EUA foram instituídas tais Cortes na década de 30, estando vinculadas aos interesses de pequenos comerciantes que não tinham acesso ao Judiciário. Destacam Cappelletti e Garth ${ }^{42}$ que o tema do acesso à Justiça, umbilicalmente ligado à judicialização das relações sociais, teve três momentos: a) a busca de uma assistência igualitária a litigantes de baixa renda, sem condições de custear despesas com um advogado; b) reformas que visaram superar a concepção individualista do processo, em prol de uma coletivista; e c) mudança dos procedimentos judiciais para tornar exequíveis os direitos, como arbitragem, conciliação, juízos de vizinhança.

No Brasil, a instituição dos Juizados Especiais proporcionou que uma série de litígios que estavam alheios ao Poder Judiciário fossem conhecidos e resolvidos

\footnotetext{
${ }^{40}$ VIANNA, Luiz Werneck et al. A judicialização da política e das relações sociais no Brasil. Rio de Janeiro: Revan, 1999. p. 259.

${ }^{41}$ VIANNA, Luiz Werneck et al. A judicialização da política e das relações sociais no Brasil. Rio de Janeiro: Revan, 1999. p. 160.

${ }^{42}$ CAPPELLETTI, Mauro; GARTH, Bryant. Acesso à justiça. Porto Alegre: S. A. Fabris Editor, 1988. p. 29.
} 
por essa instância. A instituição dos Juizados significa o momento em que o Poder Judiciário se torna reflexivo, pois busca a "litigiosidade contida" e deixa de ser um poder neutro e distante. ${ }^{43} \mathrm{~A}$ função dos Juizados é a de penetrar profundamente na sociedade e nos domínios em que a jurisdição não atingia. $\mathrm{O}$ Judiciário não pode estar em um "estandarte impenetrável", distante das reinvidicações sociais. Onde o braço do Estado não chegava, agora chega com os Juizados. Mediante a celeridade, simplicidade, economia e ampliação dos poderes do juiz, os Juizados Especiais adquiriram contornos próprios. Os Juizados retratam também a situação de exclusão social no Brasil, porque dão acesso às camadas menos abastadas. Eles são "engenheiros" ou institutional-builders, ${ }^{44}$ que atendem as crescentes demandas coletivas.

\section{0 ativismo judicial e os limites democráticos da jurisdição consti- tucional}

Luis Roberto Barroso ${ }^{45}$ afirma que judicialização e ativismo são primos, ou seja, vêm da mesma família, mas não têm a mesma origem: A judicialização é um fato que decorre do modelo constitucional adotado no Brasil, ou seja, não é um exercício voluntário de vontade política por parte dos juízes. O próprio Vianna apontou que a judicialização não foi causada por atitudes ou protagonismos dos juízes, mas por iniciativa da própria sociedade civil e da comunidade de intérpretes que bateu as portas da Justiça. ${ }^{46}$

Nisso reside uma das diferenças gritantes entre a judicialização e o ativismo: na primeira, os juízes decidem porque a Constituição exige, é o que lhes cabe; na segunda, os juízes se tornam protagonistas, pois o ativismo é uma atitude e não um fat há escolha de um modo de interpretar a Constituição, alargando ou res-

${ }^{43}$ VIANNA, Luiz Werneck et al. A judicialização da política e das relações sociais no Brasil. Rio de Janeiro: Revan, 1999. p. 155.

${ }^{44}$ VIANNA, Luiz Werneck et al. A judicialização da política e das relações sociais no Brasil. Rio de Janeiro: Revan, 1999. p. 155.

${ }^{45}$ BARROSO, Luís Roberto. Judicialização, ativismo judicial e legitimidade democrática. Revista Direito do Estado, Salvador, ano 4, n. 13, p. 71-91, jan./mar. 2009.

${ }^{46}$ VIANNA, Luiz Werneck et al. A judicialização da política e das relações sociais no Brasil. Rio de Janeiro: Revan, 1999. p. 259. 
tringindo seu alcance. Entretanto, para que haja ativismo judicial, é preciso que exista omissão ou retração do Poder Legislativo no desempenho de suas funções. A expressão "ativismo judicial" significa uma maior interferência do Judiciário na atuação dos outros poderes. Ocorrerá ativismo judicial, segundo Barroso: ${ }^{47}$ a) na aplicação direta da Constituição a situações não contempladas no seu texto e independentemente de interpositio legislatoris; b) declaração de inconstitucionalidade de atos normativos emanados do Legislativo, a partir de critérios menos rígidos que os de violação literal da Constituição; e c) imposição de condutas ou abstenções ao Poder Público, notadamente em matéria de políticas públicas.

Mas, afinal, o que é ativismo judicial? E o que o diferencia da judicialização da política? Segundo Streck:

Judicialização é contingencial. Num país como o Brasil, é até mesmo inexorável que aconteça essa judicialização (e até em demasia). Mas não se pode confundir aquilo que é próprio de um sistema como o nosso (Constituição analítica, falta de políticas públicas e amplo acesso à Justiça) com o que se chama de ativismo. O que é ativismo? É quando os juízes substituem os juízos do legislador e da Constituição por seus juízos próprios, subjetivos, ou, mais que subjetivos, subjetivistas (solipsistas). No Brasil esse ativismo está baseado em um catálogo interminável de "princípios", em que cada ativista (intérprete em geral) inventa um princípio novo. Na verdade, parte considerável de nossa judicialização perde-se no emaranhado de ativismos. ${ }^{48}$ (grifo nosso).

As origens do ativismo judicial remontam à jurisprudência norte-americana. O judicial activism foi primeiramente conservador (Dred Scott v. Sanford, 1857). Nesse caso, a atuação da Suprema Corte ofereceu amparo para a segregação racial. Na era Lochner (1905-1937), houve invalidação de leis sociais em geral, causando um confronto entre o Presidente Roosevelt e a Corte, com a mudança da orientação judicial contrária à intervenção estatal (West Coast v. Parrish, 1937). A partir de 1950, a situação se inverteu. A Corte Warren (1953-1969) e a Corte

\footnotetext{
${ }^{47}$ BARROSO, Luís Roberto. Judicialização, ativismo judicial e legitimidade democrática. Revista Direito do Estado, Salvador, ano 4, n. 13, p. 75, jan./mar. 2009.

${ }^{48}$ STRECK, Lenio Luiz; MORAIS, José Luis Bolzan de. OAB in foc, Uberlândia, ano 4, n. 20, p. 15, ago./set. 2009.
} 
Burger (até 1973) foram progressistas em matéria de direitos fundamentais, especialmente envolvendo negros (Brown v. Board of Education, 1954), acusados criminalmente (Miranda v. Arizona, 1966), mulheres (Richardson v. Frontiero, 1973), direito de privacidade (Griswold v. Connecticut, 1965), interrupção da gestação (Roe v. Wade, 1973). ${ }^{49}$

O oposto do ativismo judicial é a autocontenção judicial, em que os juízes reduzem sua interferência na esfera de outros poderes: a) evitando aplicar diretamente a Constituição a situações que não estejam não expressas no seu texto, aguardando pronunciamento do legislador; b) utilizam critérios rígidos para declaração de inconstitucionalidades de leis e atos normativos; e c) abstêm-se de interferir na definição de políticas públicas. Até antes da Constituição de 1988, essa era a atuação da Justiça no Brasil, salientando-se que o ativismo busca extrair as máximas potencialidades do texto constitucional, enquanto a autocontenção limita o âmbito de atuação dos juízes em favor das instâncias políticas. ${ }^{50}$

Oliveira ${ }^{51}$ acentua que a autorrestrição judicial ou moderação judicial implica em uma postura mais tímida do Judiciário, que passa a aceitar o resultado da disputa política legislativa, avaliando o procedimento formal, atacando somente decisões ofensivas à moralidade política ou a um precedente inequívoco, e ainda assim com muita parcimônia. No ativismo judicial, trabalha-se com cláusulas vagas e gerais.

Cittadino $^{52}$ expõe duas posições no pensamento jurídico norte-americano: os interpretativistas e os não-interpretativistas. O interpretativismo sustenta, baseado em Joseph Story (Commentaries on the Constitution of the United States, 1873),

${ }^{49}$ BARROSO, Luís Roberto. Judicialização, ativismo judicial e legitimidade democrática. Revista Direito do Estado, Salvador, ano 4, n. 13, p. 71-91, jan./mar 2009.

${ }^{50}$ BARROSO, Luís Roberto. Judicialização, ativismo judicial e legitimidade democrática. Revista Direito do Estado, Salvador, ano 4, n. 13, p. 76, jan./mar. 2009.

${ }^{51}$ OLIVEIRA, Cláudio Ladeira de. Ativismo judicial, autorestrição judicial e o "minimalismo" de Cass Sustein. Disponível em: <http://www.diritto.it/archivio/1/27004.pdf>. Acesso em: 22 dez. 2009.

52 CITTADINO, Gisele. Pluralismo, direito e justiça distributiva. 4. ed. Rio de Janeiro: Lumen Júris, 2009. p. 25-27. 
e posteriormente em Robert Bork e W. Rehnquist, que a Constituição deve ser interpretada literalmente, que seu texto deve ser tomado na sua acepção natural e óbvia, evitando-se o alargamento ou restrição do seu alcance. Fundada em uma matriz liberal, defende uma interpretação jurídica presa ao princípio da legalidade. O não-interpretativismo aceita lidar com princípios, não leva em consideração somente o texto, mas invoca o processo histórico, os precedentes, o ethos social (Bruce Ackerman e Dworkin). Nesse sentido, o non interpretativism (re) interpreta a legalidade, na medida em que não importa tanto o sentido literal do texto, mas seu sentido na comunidade histórico-concreta, constituída a partir de princípios de moralidade política. O não-interpretativismo pode dar azo ao ativismo judicial na medida em que permite com que os juízes julguem a partir de cláusulas gerais e termos indeterminados (embora suas decisões possam ser conservadoras e não necessariamente progressistas).

Giacomuzzi $i^{53}$ alerta para o fato de que não há sentido em defender um ativismo judicial ou uma autorrestrição judicial de forma descontextualizada, porque tais termos só têm sentido historicamente. Nos EUA, quando um tribunal decide contra uma lei progressista, advoga-se o self-restraint; se o Tribunal não anula uma lei progressista, então os conservadores defendem o judicial activism. Portanto, ambos os termos perdem sentido, porque são usados pelos oportunistas para disfarçarem sua ideologia. Os mesmos que defendem em certos casos o judicial activism em outros, poderão, a partir do que lhes for conveniente, advogar a judicial restraint.

Streck critica o ativismo judicial que, segundo ele, não é bom para a democracia. Substancialmente, defende o autor que o ativismo judicial tem significado, na prática, que os juízes decidem como querem, ou seja, quando não concordam com uma lei, constroem um princípio (pan-principiologismo):

[...] Os juízes (e a doutrina também é culpada), que agora deveriam aplicar a Constituição e fazer filtragem das leis ruins, quer dizer, aquelas inconstitucionais, passaram a achar que sabiam mais do que o constituinte. Saímos,

\footnotetext{
${ }^{53}$ GIACOMUZZI, José Guilherme. As raízes do realismo americano: breve esboço acerca de dicotomias, ideologia e pureza no direito dos USA. Revista de Direito Administrativo, Rio de Janeiro, n. 239, p. 359-388, jan./mar. 2005.
} 
assim, de uma estagnação para um ativismo, entendido como a substituição do Direito por juízos subjetivos do julgador. Além disso, caímos em uma espécie de panprincipiologismo, isto é, quando não concordamos com a lei ou com a Constituição, construímos um princípio. Pergunto: se estamos de acordo que princípio é norma (e tem mais de 200 teses de doutorado dizendo isso), o que fazer com um princípio como o da cooperação processual, da monogamia, da situação excepcional consolidada ou da confiança no juiz da causa? Há até um princípio denominado de moderação, utilizado para reduzir honorários. [...] AeradosprincípiosnãoveioparatransformaroDireitoem um império de decisões baseadas na consciência individual de cada julgador. Princípios têm a função de resgatar o mundo prático no Direito. Por outro lado, decisionismos e/ou ativismos não são bons para a democracia. Se cada um decide como quer, os tribunais - mormente o STJ e o STF - acabam entulhados de processos. No fundo, a repercussão geral e as súmulas são uma resposta darwiniana a uma espécie de estado de natureza hermenêutico que criamos. Veja só: se fundamentarmos cada decisão até o limite, teremos uma maior accountabillity [prestação de contas em cada decisão]. Mais: se anulássemos decisões mal fundamentadas, não teríamos essa proliferação de embargos declaratórios. Sugiro, portanto, que cumpramos o artigo 93, inciso IX, da Constituição Federal [estabelece que os julgamentos têm que ser públicos e as decisões, fundamentadas] que, antes de ser um direito, é um dever fundamental do juiz. ${ }^{54}$

Como é possível observar, o autor equipara o ativismo judicial à decisionismos ou discricionariedades dos juízes, que decidem muitas vezes à revelia do pacto constituinte e do texto constitucional. ${ }^{55}$ É flagrante que a crítica é relevante, na medida em que há um "risco hermenêutico" no ativismo judicial, consisten-

${ }^{54}$ STRECK, Lenio Luiz; MORAIS, José Luis Bolzan de. Ativismo judicial não é bom para a democracia. Disponível em: <http://leniostreck.com.br/index. php?option=com_ content\&task $=$ view\&id= 87\&Itemid= 1>. Acesso em: $22 \mathrm{dez} .2009$.

${ }^{55}$ É preciso explicar que o autor critica o "ativismo judicial" entendido como sinônimo de "decisionismo judicial", mas não as decisões concessivas de direitos ou posturas ativas do Judiciário, visando à concretização da Constituição. Isso fica mais claro quando se observa que Lenio Streck se afilia ao substancialismo. A respeito, cf. STRECK, Lenio Luiz; MORAIS, José Luis Bolzan de. Verdade e consenso. Rio de Janeiro: Lumen Júris, 2008. p. 138. 
te na possibilidade do Judiciário substituir de forma não democrática os juízos do legislador ou dos membros do Executivo pelos seus. É preciso convir que as críticas ao ativismo judicial dos juízes em certas circunstâncias ou de certa Corte escondem certas preferências político-ideológicas (embate entre conservadores e progressistas), taxando de ilegítimas certas decisões judiciais que extrapolam os limites democráticos. Como é preciso considerar, é tarefa árdua, complexa e discutível delimitar até que ponto a jurisdição constitucional atua democraticamente, porquanto envolve um conjunto de tradições e concepções de democracia, ou seja, isso remonta ao que é democracia (pergunta sempre debatida) e à função democrática dos tribunais.

Cittadino $^{56}$ sustenta que o ativismo judicial faz parte do processo de judicialização da política e questiona até que ponto os juízes têm legitimidade para desafiar a deliberação pública de uma comunidade autônoma. Segundo a autora, "Dar uma resposta positiva a essa pergunta significa, na verdade, autorizar os tribunais, especialmente as cortes supremas, a atuarem como profetas ou deuses do direito, consolidando aquilo que já é designado como 'teologia constitucional' [... ]". ${ }^{57}$ Carvalho ${ }^{58}$ pergunta:

Neste ponto há que se questionar: em que medida o ativismo judicial promove ou afronta a democracia? Qual é o risco de se fundar um aristocrático governo de juízes, uma juristocracia, exercida sob o falacioso manto de uma atividade aparentemente técnica de interpretação normativa?

O fenômeno da judicialização da política, especialmente no Supremo Tribunal Federal, significa o enfrentamento de temas árduos da vida política pela Corte, que tem a obrigação de decidi-las. Isso é uma judicialização dos conflitos que acaba por tornar cada vez mais o Poder Judiciário inserido em grandes proble-

\footnotetext{
${ }^{56}$ CITTADINO, Gisele. Poder Judiciário, ativismo judiciário e democracia. Alceu, Rio de Janeiro, v. 5, n. 9, p. 105-113. jul./dez. 2004.

${ }^{57}$ CITTADINO, Gisele. Poder Judiciário, ativismo judiciário e democracia. Alceu, Rio de Janeiro, v. 5, n. 9, p. 105-113. jul./dez. 2004.

${ }^{58}$ CARVALHO, Carlos Araújo de. Ativismo judicial em crise. Disponível em: < http://jus2. uol.com.br/doutrina/texto.asp?id=12781>. Acesso em: 23 dez. 2009.
} 
mas políticos nacionais, o que lhe dá proeminência e possibilita o controle judicial do jogo político.

\subsection{O ativismo na jurisdição constitucional brasileira}

Acerca do ativismo judicial são elucidativas as palavras de William Van Alstyne, na obra Judicial Power and the Constitution. ${ }^{59}$ Diz o autor que judicial activism e judicial restraint são termos indicativos de como diferentes Cortes e juízes conduzem a si mesmos em suas decisões, ou seja, remetem a dois extremos opostos. Por um lado, o modelo extremado do ativismo judicial de uma corte tão intrusiva e onipresente que praticamente domina a instituição do governo; como antítese desse modelo, uma Corte que não decide nada encontra razões para a sua "ausência" de jurisdição e permite a deferência à superioridade de outros departamentos e agências na construção do Direito, elenca razões pelos quais a constitucionalidade das leis não pode ser examinada, deixando de impor limites constitucionais.

Os usos dos termos "ativismo judicial" e "autocontenção judicial" não são uniformes nos Estados Unidos. Às vezes, são utilizados como mera descrição para identificar como certas cortes ou juízes são mais ativistas ou mais contidos que outros, ou mais do que parecem ser. Nesse sentido, o uso não representa nem uma censura nem um aplauso. É especialmente em face da Suprema Corte norte-americana que os termos são manipulados polemicamente, ou seja, como uma visão do que é "correto" ou "errado" em termos decisórios (aproximando-se do conceito de ideologia). A partir da postura procedimentalista ou substancialista da Corte, ou de quanto ativista ou contida deveria ser na utilização do judicial review, críticos taxam-na de ativista ou acusam-na de self-restraint.

O ativismo procedimental (procedural activism) depende do rigor ou da falta de rigor com o qual a Corte interpreta as limitações constitucionais, ou do fato de ela adjudicar ou não o mérito de um problema constitucional a outras

\footnotetext{
${ }^{59}$ ALSTYNE, William Van. Judicial activism and judicial restraint. In: LEVY, Leonard W; KARST, Kenneth L; MAHONEY, Dennis (Org.). Judicial power and the Constitution. New York: Macmillan Publishing Company, 1990. p. 58-72.
} 
instâncias. O ativismo substancial (substancial activism) pode ser analisado em três partes, cada uma refletindo a extensão pela qual a Corte interpreta a Constituição, mesmo agressivamente, para invalidar ações tomadas por outros departamentos do governo. Em primeiro lugar, cumpre aferir as interpretações substantivas que a Corte faz dos poderes enumerados de outros departamentos do governo. Em segundo lugar, qual é o seu entendimento quanto à variedade de poderes não explicitamente mencionados e proibidos a eles na Constituição. Em terceiro lugar, importa a interpretação da Corte das cláusulas constitucionais que impõe restrições positivas ao governo. ${ }^{60}$

Uma forte influência para a autocontenção judicial foi a de James Bradley Thayer, em 1893, ao sustentar que o Executivo e o Departamento Legislativo do governo nacional são constitucionalmente iguais ao Judiciário, e mais representativos do povo do que os membros da Suprema Corte. A Corte somente teria legitimidade para questionar atos do governo manifestamente equivocados e não em caso de inconstitucionalidade conformada por particulares interpretações que os juízes tiveram independentemente do posicionamento do governo. Ao propor uma extreme judicial deference quanto aos poderes governamentais, Thayer não tinha em mente um Judiciário como guardião da Constituição, mas como uma instituição que validasse as exigências da autoridade nacional.

É preciso realçar o significado do termo "ativismo judicial" no presente trabalho. Primeiramente, cumpre trazer à tona a lição de Habermas, quando sustenta que não há como sustentar que o ativismo judicial é algo bom ou ruim a priori, ou seja, independentemente do contexto em que é analisado e das posições dos juízes. Daí porque o ativismo judicial poderá se manifestar ou se desvelar (alethéia) como criticável em certos contextos e em outros não. Dizer que o ativismo judicial é algo ruim em si mesmo não é compatível com a tradição norte-americana.

O ativismo judicial também não deve ser utilizado como "palanque retórico do crítico", ou seja, não basta taxar uma Corte de ativista para que ela efetivamente

\footnotetext{
${ }^{60}$ ALSTYNE, William Van. Judicial activism and judicial restraint. In: LEVY, Leonard W; KARST, Kenneth L; MAHONEY, Dennis (Org.). Judicial power and the Constitution. New York: Macmillan Publishing Company, 1990. p. 64.
} 
o seja. Para tanto, é necessário que efetivamente, como bem demonstrou Alstyne, ${ }^{61}$ existam posições jurisprudenciais que afirmem a possibilidade da própria Corte decidir certas questões cruciais ao invés de adjudicá-las a outras instâncias, assumindo sua própria legitimidade política, interprete com rigor certas limitações constitucionais em face do governo, invalidando seus atos, restringindo seus poderes, diante de omissões inconstitucionais assuma uma postura ativa, resolvendo por si mesma a questão, ao invés de realizar uma deferência para com o governo ou imponha condutas.

O ativismo poderá ser conservador ou progressista, dependendo dos posicionamentos dos juízes. Mas a crítica ao ativismo judicial deverá ser sempre casuística ou contextualizada. Daí porque muitos elogiam o ativismo progressista da Corte Warren e criticam o ativismo conservador da Corte Lochner. Mas o pano de fundo das críticas ao ativismo judicial repousa na própria capacidade representativa do Poder Judiciário. À medida que os juízes começam a decidir certa matéria que sempre foi pacificamente delegada ao parlamento, os críticos alegam violação da separação de poderes, mas resta questionar se na prática existe esta separação radical de poderes e se não deveria haver um trabalho conjunto dos poderes em nome do Estado.

A tese da autocontenção judicial também é problemática, porque em muitos casos nela repousa um Judiciário subserviente aos demais Poderes (como na França). O ativismo aqui trabalhado é intimamente correlato à judicialização da política, pois à medida que cada vez mais questões políticas chegam ao Poder Judiciário para serem resolvidas, fica mais fragilizada a separação entre governo (Executivo e Legislativo) e Judiciário, porque este deve controlar os atos do governo e não ficar distante dele.

Ao trabalhar com questões políticas e avocar sua própria legitimidade para decidi-las, o Judiciário, por vezes, assume posturas interventivas e ativas em face

${ }^{61}$ ALSTYNE, William Van. Judicial activism and judicial restraint. In: LEVY, Leonard W; KARST, Kenneth L; MAHONEY, Dennis (Org.). Judicial power and the Constitution. New York: Macmillan Publishing Company, 1990. p. 58-72. 
dos demais poderes; mas, ao invés de criticar a "invasão" dos juízes na esfera de outros poderes, restaria questionar se em terrae brasilis, em que a Constituição sofre com omissões legislativas inconstitucionais, resta legitimo aos juízes se eximir da responsabilidade diante da inércia do legislador, quando o que mais importa é a concretização dos direitos fundamentais e sociais. ${ }^{62}$

Nesse sentido, uma definição de ativismo judicial, na esteira de Alstyne, ${ }^{63}$ é visualizá-lo como um conjunto de decisões jurisprudenciais que entendam que o Judiciário tem legitimidade para decidir certas questões políticas cruciais ao invés de adjudicá-las às instâncias tradicionais parlamentares ou executivas ou ao autocontrole delas (Habermas). Em suma, o que é comum ao ativismo judicial é o questionamento da legitimidade política de certas posições dos juízes. ${ }^{64}$

Assim, ao argumento de que a concretização de direitos via judiciário (jurisdição constitucional) enfraquece a cidadania e coloca em risco a própria democracia (sic), cabe lembrar que não há qualquer registro de que a democracia tenha sido colocada em xeque em face de decisões judiciárias concessivas de direitos, consideradas como "jurisprudência dos valores", "ativismo judicial", etc. ${ }^{65}$

${ }^{62}$ A respeito da concretização de tais direitos, cf. SARLET, Ingo. A eficácia dos direitos fundamentais. 2. ed. Porto Alegre: Livraria do Advogado, 2001. e também SARLET, Ingo. Dignidade da pessoa humana e direitos fundamentais. 3. ed. Porto Alegre: Livraria do Advogado, 2004.

${ }^{63}$ ALSTYNE, William Van. Judicial activism and judicial restraint. In: LEVY, Leonard W; KARST, Kenneth L; MAHONEY, Dennis (Org.). Judicial power and the Constitution. New York: Macmillan Publishing Company, 1990. p. 58-72.

${ }^{64}$ Em artigo de Rodrigo de Souza Tavares, José Ribas Vieira e Vanice Regina Lírio do Vale, fica bastante claro que é inviável fornecer uma definição única de "ativismo judicial" que englobe todas as suas possibilidades. Ao definir "ativismo judicial", o que geralmente se faz é adotar certa perspectiva. É possível, entretanto, entrever uma série de "indicadores" de ativismo judicial, como o contramajoritarismo, o não-originalismo, a ausência de deferência judicial perante os precedentes judiciais, o ativismo jurisdicional, a criatividade judicial, o ativismo remedial e o ativismo partidário. $\mathrm{O}$ ativismo jurisdicional é a recusa dos Tribunais de manterem-se dentro dos limites jurisdicionais estabelecidos para o exercício de seus poderes. Cf. TAVARES, Rodrigo de Souza et al. Ativismo jurisdicional e o Supremo Tribunal Federal. In: CONGRESSO NACIONAL DO CONPEDI, 17, 2008, Brasília. Anais... Brasília, 2008.

${ }^{65}$ STRECK, Lenio Luiz; MORAIS, José Luis Bolzan de. Verdade e consenso. Rio de Janeiro: Luhmen Júris, 2008. p. 138. 
Conforme leciona Barroso, ${ }^{66}$ são três as grandes críticas que podem ser feitas ao ativismo judicial: a) ele configura riscos para a legitimidade democrática; b) ocasiona a politização indevida da Justiça; e c) desafia os limites da capacidade institucional do Poder Judiciário. Embora os juízes não sejam eleitos, há duas justificativas para o contramajoritarismo exercido por eles: um fundamento normativo, que consiste na própria Constituição atribuir ao Poder Judiciário o dever de controlar as deliberações políticas dos outros poderes, e um fundamento filosófico, que sustenta que a jurisdição constitucional é antes uma garantia que um risco. Sua legitimidade, porém, só pode advir da fundamentação racional de suas decisões.

De qualquer forma, não haveria sustentação para se negar que a deliberação dos parlamentares e dos membros do Executivo também acarreta riscos permanentes à democracia, na medida em que os mandantes eleitos do povo podem violar a vontade soberana do poder constituinte ou ir contra os anseios populares. O que é recriminável no ativismo judicial ocorre quando juízes ${ }^{67}$ impõem suas próprias escolhas, preferências e sua vontade à revelia do pacto constituinte e dos princípios constitutivos de uma sociedade, ou seja, atuam como se fossem mônadas isoladas, que julgam a partir de um estandarte impenetrável, alheios à sociedade, como se pudessem justificar a autoridade de suas decisões a partir de si mesmos. Não se pode esquecer que, nos termos do art. 1, parágrafo único da Constituição, todo poder emana do povo.

Os riscos da politização da justiça remontam a Schmitt, ${ }^{68}$ que alertava para os riscos de uma aristocracia de toga e dizia que a justiça perderia assim sua independência e imparcialidade. Entretanto, parecem utópicas as pretensões de desvincular o Poder Judiciário da Política, na medida em que ele trabalha com pro-

${ }^{66}$ BARROSO, Luís Roberto. Judicialização, ativismo judicial e legitimidade democrática. Revista Direito do Estado, Salvador, ano 4, n. 13, p. 78, jan./mar 2009.

${ }^{67}$ BARROSO, Luís Roberto. Judicialização, ativismo judicial e legitimidade democrática. Revista Direito do Estado, Salvador, ano 4, n. 13, p. 71-91, jan./mar 2009.

${ }^{68}$ A respeito, cf. SCHMITT, Carl. O guardião da Constituição. Belo Horizonte: Del Rey, 2007. p. 83. Diz Schmitt: "Hoje, tais planos de uma "jurisdicização" da política são avaliados, provavelmente, com mais consciência e se reconhecem melhor as fronteiras da estrutura judicial que têm que ser protegidas justamente no interesse da justiça independente e do Estado de Direito contra a politização partidária”. 
dutos da política (as leis), ou seja, com suas deliberações. Como julgá-lo capaz de manter-se impermeável aos seus influxos?

Desde cedo, a teoria crítica do Direito ${ }^{69}$ tem denunciado que Direito é Política. Em que pese ao exagero da equiparação radical entre Direito e Política, não se pode deixar de entrever verdades na teoria crítica, especialmente quando manifesta a existência de ideologias e superestruturas de poder no Direito. Dizer que é impossível elidir da jurisdição a Política não significa afirmar que as decisões devem ser políticas. Implica em afirmar que a decisão judicial não pode ser discricionária, que o juiz é um ser humano, com sua subjetividade e seu inconsciente, e que não pode ficar alheio à realidade política e aos efeitos políticos de sua decisão. Mas se tomarmos a expressão "Política" como sinônimo de arbitrariedade, de parcialidade, de simples jogo de força, certamente a decisão judicial não pode ser política, porque isso implicaria a perda da sua legitimidade ou reconhecimento. $O$ contramajoritarismo, quando defensor dos direitos fundamentais, ao invés de ir contra a maré democrática, ruma em seu favor, preservando a Constituição. ${ }^{70}$

Quanto aos limites da capacidade institucional do Poder Judiciário, é preciso considerar dois problemas: a) em matérias de grande complexidade, que demandem grande conhecimento técnico de aspectos científicos, o juiz pode não ser o mais qualificado, por falta de informação e conhecimento específico; e b) em matéria de efeitos sistêmicos imprevisíveis, uma decisão judicial pode ter impactos inesperados, demonstrando a incapacidade do juiz de visualizar os possíveis danos que poderá advir de sua decisão. Tem sido criticada a excessiva intervenção do Judiciário nas políticas de saúde. Muitos sustentam que sua postura ativista tem ocasionado um "rombo" no orçamento público e comprometido as atividades dos outros Poderes. ${ }^{71}$ Uma das razões apresentadas para negar à jurisdição constitucional o trato de questões políticas, em Carl Schmitt, é exatamente a incapaci-

\footnotetext{
${ }^{69}$ A respeito da teoria crítica do Direito, cf. o trabalho de ROCHA, Leonel Severo. Epistemologia jurídica e democracia. 2.ed. São Leopoldo: Ed. Unisinos, 2005. p. 57.

${ }^{70}$ BARROSO, Luís Roberto. Judicialização, ativismo judicial e legitimidade democrática. Revista Direito do Estado, Salvador, ano 4, n. 13, p. 81, jan./mar 2009.

${ }^{71}$ BARROSO, Luís Roberto. Judicialização, ativismo judicial e legitimidade democrática. Revista Direito do Estado, Salvador, ano 4, n. 13, p. 82, jan./mar 2009.
} 
dade institucional da Justiça em abarcar questões que extrapolam seu âmbito de apreciação. ${ }^{72}$

No presente trabalho, serão brevemente avaliados alguns julgamentos do STF e do TSE em que se discute a existência de ativismo judicial. Primeiramente, cumpre avaliar a Resolução n. 22.610/07 do TSE ${ }^{73}$ juntamente com a ADIn 3.999 do $\mathrm{STF}^{74}$ e o Mandado de Injunção 670 de $2008 .^{75} \mathrm{Na}$ Resolução supramencionada, o TSE instituiu a perda do mandato por infidelidade partidária, regra que não consta no texto constitucional. Na ADIN 3.999, alega-se que o TSE usurpou competência do Legislativo e do Executivo para dispor sobre matéria eleitoral. Sustentou o STF que, enquanto o Legislativo não suprir tal lacuna, a manifestação do TSE é legítima, pois visa resguardar a fidelidade partidária. O STF, na Adin 3.999, julgou constitucional a Resolução. No Mandado de Injunção n. 670, o STF decidiu - modificando seu posicionamento anterior - aplicar as regras da greve do servidor público à iniciativa privada, analogicamente. Considerou a Corte evoluindo sensivelmente a sua jurisprudência - que o Congresso tinha 60 dias para elaborar diploma legislativo e que aplicar-se-iam supletivamente as Leis n. $7.701 / 1988$ e $7.783 / 1989$.

${ }^{72}$ A respeito, cf. SCHMITT, Carl. O guardião da Constituição. Belo Horizonte: Del Rey, 2007. p. 83. Afirma Schmitt: "Pela natureza da matéria, o funcionalismo público de carreira está restrito à justiça e à administração. Por conseguinte, ele obtém da legislação ou do governo suas normalizações ou diretivas decisivas. Ele é incapaz de tomar, por si, a decisão política e determinar, sob normas e critérios de sua tecnicidade, as diretrizes da política. Ele pode obstar, deter e, nesses moldes, acionar seu efeito neutralizador, mas não decidir e governar no sentido verdadeiro da palavra". (grifo do autor).

${ }^{73}$ BRASIL. Tribunal Superior Eleitoral. Resolução n. 22.610/07. Relator: Min. Cezar Peluso. Disponível em: <http://www.tse.gov.br/internet/jurisprudencia/index.htm>. Acesso em: 26 dez. 2009.

${ }^{74}$ BRASIL. Supremo Tribunal Federal. Ação Direta de Inconstitucionalidade n. 3.999. Partido Social Cristão e Tribunal Superior Eleitoral. Relator: Joaquim Barbosa. 12 de novembro de 2008. Disponível em: < http://www.stf.jus.br/portal/inteiroTeor /pesquisarInteiroTeor.asp\#resultado $>$. Acesso em: 26 dez. 2009.

${ }^{75}$ BRASIL. Supremo Tribunal Federal. Mandado de Injunção n. 670. Sindicato dos Servidores Policiais Civis e Congresso Nacional. Relator: Min. Gilmar Mendes. 25 de Outubro de 2007. Disponível em: < http://www.stf.jus.br/portal/inteiroTeor/ pesquisarInteiroTeor. asp\#resultado >. Acesso em: 26 dez. 2009. 
De tais julgados, podem-se elaborar algumas questões: a) tinha o TSE legitimidade democrática para instituir uma regra eleitoral válida nacionalmente (relativa à perda do mandato por infidelidade partidária) mesmo com ausência expressa de texto constitucional nesse sentido, considerando a omissão legislativa do Congresso Nacional? b) o STF tinha legitimidade institucional para suprir a omissão legislativa no mandado de injunção, determinando que fossem aplicadas analogicamente às leis da greve do servidor público? O ativismo judicial do TSE foi duramente criticado: alegou-se que o Tribunal estaria legislando. ${ }^{76}$ Quanto à decisão do STF no Mandado de Injunção 670, o ativismo judicial da Corte foi elogiado como um resgate do próprio instituto do mandado de injunção, que havia perdido sua credibilidade pela postura passiva que os Ministros haviam adotados em julgados anteriores. O STF simplesmente notificava o Congresso Nacional de sua mora legislativa. Com essa celebrada decisão, efetivamente o instituto passou a ser uma garantia constitucional.

Em muitos casos o ativismo judicial é a única salvaguarda do cidadão. Se o STF não tivesse modificado o seu posicionamento, até hoje a garantia do mandado de injunção seria letra morta, porque o Congresso Nacional não cumpre as notificações do Supremo Tribunal Federal. A decisão do TSE que determinou a existência da fidelidade partidária, em que pese a todas as críticas que sofreu, estava baseada no princípio da moralidade, segundo o qual o cargo não é patrimônio do titular do mandato, pois ele foi eleito em certo partido e não pode mudar irresponsavelmente de sigla, como se não tivesse de prestar contas ao cidadão (accountability). Portanto, diante da omissão legislativa em disciplinar tal instituto, o TSE assumiu uma postura interpretativa ativa, determinando o cumprimento direto do mandamento do princípio da moralidade, este sim expresso na Constituição, independentemente de interpositio legislatoris. No âmbito do mandado de injunção, não se pode conceber o STF como um mero "notificador" de omissões do Congresso Nacional (como se este não soubesse que está em mora!).

\footnotetext{
${ }^{76}$ A respeito, cf. LAGO, Rodrigo Pires Ferreira. O Supremo constituinte: uma visão crítica do ativismo judicial do Supremo Tribunal Federal. Jus Navigandi, Teresina, ano. 14, n. 2319, 6 nov. 2009. Disponível em: <http://jus2.uol.com.br/ doutrina/texto.asp?id=13805>. Acesso em: 22 dez. 2009.
} 
A crise política de representatividade é tamanha que a jurisdição constitucional se tornou em muitos casos a última porta. Se os juízes não são ativistas, terminam muitas vezes por assumir posturas não-concretistas ${ }^{77}$ incompatíveis com a Constituição. É claro que a hermenêutica, entendida como "arte ou técnica (método), com efeito diretivo sobre a lei divina e a lei humana", ${ }^{78}$ denuncia os riscos do ativismo judicial. Tais riscos se tornam exponenciais quando o juiz distancia-se da tradição e da história constitucional e decide como bem entende. Mas tais riscos não invalidam o fato de que o ativismo judicial, com todos os seus problemas, por vezes é uma necessidade. Mesmo que se entenda que a via ideal é a democracia e que o Parlamento é o caminho correto para instituir e preservar direitos, dada a omissão do legislador, não se pode esperar dos juízes uma postura não-concretista, tornando-os reféns de interposições legislativas. Afinal de contas, ao cidadão importa tão somente a concretização de suas expectativas e não os problemas de que quem afinal tem legitimidade democrática para concretizá-las.

\section{A democracia constitucional em Ronald Dworkin}

Como salienta Lucas, ${ }^{79}$ na esteira de Cappelletti, o ativismo judicial não pode ser considerado antidemocrático simplesmente por ser contramajoritário, pois os Tribunais podem dar voz às minorias ou solucionar graves problemas decorrentes da ausência de consenso político do governo, arraigado ao fisiologismo. Logo, o problema real deve ser direcionado ao grau de representatividade dos Tribunais, ao invés de taxá-los a priori de antidemocráticos.

Uma nota final: o ativismo judicial, até aqui, tem sido parte da solução, e não do problema. Mas ele é um antibiótico poderoso, cujo uso deve ser eventual e controlado. Em dose

\footnotetext{
77 A respeito das posições concretistas e não-concretistas, cf. a classificação de Alexandre de Moraes em face das posturas interpretativas do STF no mandado de injunção. MORAES, Alexandre de. Direito constitucional. 23. ed. São Paulo: Atlas, 2008. p. 174.

${ }^{78}$ STRECK, Lenio Luiz. Hermenêutica. In: BARRETO, Vicente de Paulo (Coord.) Dicionário de Filosofia do Direito. São Leopoldo: Editora Unisinos; Rio de Janeiro: Editora Renovar: 2006. p. 430-434.

${ }^{79}$ LUCAS, Doglas Cesar. A crise funcional do Estado e o cenário da jurisdição desafiada. In: MORAIS, José Luis Bolzan de (Org.). O Estado e suas crises. Porto Alegre: Livraria do Advogado, 2005. p. 207.
} 
excessiva, há risco de se morrer da cura. A expansão do Judiciário não deve desviar a atenção da real disfunção que aflige a democracia brasileira: a crise de representatividade, legitimidade e funcionalidade do Poder Legislativo. Precisamos de reforma política. E essa não pode ser feita por juízes. ${ }^{80}$

Dworkin ${ }^{81}$ tem uma concepção muito reflexiva de democracia. Ele trabalha com grande acuidade o problema da legitimidade da jurisdição constitucional. $\mathrm{O}$ cerne da polêmica, em Dworkin, consiste na atitude do candidato à Presidência dos Estados Unidos, Richard Nixon, de nomear à Suprema Corte somente juristas adeptos do "construcionismo estrito", ou seja, strict constructism, segundo o qual, na interpretação da lei, o jurista deve se ater à sua letra, impedindo-se de ampliar o seu significado, mesmo pela analogia, e não podendo analisar suas implicações, equidade e objetivos sociais. Considerar os fins subjacentes da lei distorceria ou "dobraria" o Direito.

As posições de Nixon são nitidamente conservadoras. A razão pelo qual os juízes são facilmente enquadrados como "liberais" ou "conservadores" é esta: eles sustentam certas concepções de moralidade política e pública nos seus julgamentos, demonstram convicções políticas e ideários. Os juízes liberais e os conservadores, portanto, comungam de diferentes concepções de moralidade política, ou seja, não concordam quanto aos princípios e valores morais e políticos de conduta do homem, o que acarreta divergências quanto à constitucionalidade de certas práticas. $\mathrm{O}$ conservador supõe que o homem de bem gostaria de ser tratado em conformidade com os princípios de um tipo especial de sociedade, a sociedade virtuosa, ${ }^{82}$ e que a virtude decorre da experiência e historia da comunidade. ${ }^{83}$ Os conservadores tentam convencer infrutiferamente o povo de que as grandes questões constitucionais não giram em torno de questões morais. Há uma farsa ou demagogia que afirma que os juízes julgam neutramente e com obediência ao texto legal.

\footnotetext{
${ }^{80}$ BARROSO, Luís Roberto. Judicialização, ativismo judicial e legitimidade democrática. Revista Direito do Estado, Salvador, ano 4, n. 13, p. 84, jan./mar 2009.

${ }^{81}$ A respeito, cf. DWORKIN, Ronald. Levando os direitos a sério. São Paulo: M. Fontes, 2002. p. 206.

82 DWORKIN, Ronald. Uma questão de princípios. São Paulo: M. Fontes, 2001. p. 296.

${ }^{83}$ DWORKIN, Ronald. Uma questão de princípios. São Paulo: M. Fontes, 2001. p. 297.
} 
Dada a extensão da argumentação dworkiana, podemos sintetizar seu pensamento da seguinte maneira: considerar que os tribunais não são democraticamente legítimos para decidir certas questões pressupõe que somente órgãos políticos como o Legislativo são politicamente responsabilizáveis, o que não é verdade. As decisões sobre os direitos da maioria não devem ser, exalta Dworkin, decididas por elas próprias, pois isto é um pressuposto do constitucionalismo. É certo que o ativismo judicial envolve riscos de tirania, mas a maioria democrática congressista não pode julgar em causa própria. ${ }^{84}$ Não é salutar à democracia que a maioria julgue em causa própria, e o próprio constitucionalismo rejeita a absolutização do caráter majoritário das deliberações parlamentares. Ou seja, é um contrassenso considerar democrática a decisão das maiorias parlamentares se elas não se sujeitarem ao judicial review.

Para ilustrar seu argumento, Dworkin utiliza um argumento (de índole psicológica e familiar), segundo o qual, o pai (que representa a tradição), ao ensinar a seus filhos um conceito de justiça e esperar que não tratem injustamente os outros, não poderia pensar todas as hipóteses de aplicação de suas máximas pelos seus filhos e deveria admitir que, se um filho o convencesse de que um ato que ele julgava justo era injusto, ele deveria incluí-lo nas suas instruções, pois a família deveria se guiar pelo conceito de justiça ou fairness e não por uma concepção particular de justiça. ${ }^{85}$ Nesse sentido, o que fica exposto é que a tradição acerca do que é justo pode ser aprimorada pelos discípulos e importa mais do que pensavam os seus pais em suas concepções particulares de justiça, pois importa o conceito de justiça. É necessário entender que Dworkin concebe a justiça "como correta distribuição dos discursos existentes entre os membros da sociedade". ${ }^{86}$

O programa do ativismo judicial sustenta que os tribunais devem aceitar a orientação das chamadas cláusulas constitucionais vagas no sentido que descrevi [...] Devem desenvolver princípios de legalidade, igualdade e assim por

\footnotetext{
${ }^{84}$ Cf. DWORKIN, Ronald. Levando os direitos a sério. São Paulo: M. Fontes, 2002. p. 225.

${ }^{85}$ DWORKIN, Ronald. Levando os direitos a sério. São Paulo: M. Fontes, 2002. p. 211.

${ }^{86}$ OLIVEIRA, Cláudio Ladeira de. Direito como integridade e ativismo judicial: algumas considerações acerca de uma decisão do Supremo Tribunal Federal. Disponível em: <http:// www.buscalegis.ufsc.br /revistas/index. php/buscalegis /article/ viewFile/33059/32237> Acesso em: 28 out. 2010.
} 
diante, revê-los de tempos em tempos à luz do que parece ser a visão moral recente da Suprema Corte, e julgar os atos do Congresso, dos Estados e do presidente de acordo com isso $[\ldots]$

Ao contrário, o programa da moderação judicial afirma que os tribunais deveriam permitir a manutenção das decisões de outros setores do governo, mesmo quando elas ofendam a própria percepção que os juízes têm dos princípios exigidos pelas doutrinas constitucionais amplas, excetuando-se, contudo, os casos nos quais essas decisões sejam tão ofensivas à moralidade política a ponto de violar as estipulações de qualquer interpretação plausível, ou, talvez, nos casos em que uma decisão contrária for exigida por um precedente inequívoco. $[\ldots]^{87}$

É, sobretudo, nas críticas ao princípio majoritário que transparece uma das grandes contribuições à democracia em Dworkin. Ele sustenta que a premissa majoritária, ao invés de ser endeusada, deve ser criticada, porque:

a) mesmo aqueles que a exaltam como norte da democracia dizem que, em certas ocasiões, a vontade da maioria não deve prevalecer, que não pode ser juíza de si mesma, que suas ações podem prejudicar direitos individuais ou minorias. Acentuam que a atenuação do poder majoritário, às vezes, é necessária, mas é sempre lamentável e sempre injusta;

b) a partir concepção constitucional da democracia, que é qualitativa, pois intimamente vinculada à igualdade, e não quantitativa, a decisão do Tribunal é democrática se restaura a igualdade violada entre os cidadãos, ou seja, o objetivo da democracia não é a expressão da vontade majoritária, mas sim que as instituições dediquem o mesmo respeito e consideração a todos os indivíduos. Portanto, quando é necessário para restaurar a igualdade, a democracia deve valer-se de procedimentos não-majoritários. ${ }^{88}$ Portanto, não há motivo para um tribunal não rejeitar a premissa majoritária na derrubada de uma lei inconstitucional segundo a

\footnotetext{
${ }^{87}$ DWORKIN, Ronald. Levando os direitos a sério. São Paulo: M. Fontes, 2002. p. 215.

${ }^{88}$ DWORKIN, Ronald . O direito da liberdade: a leitura moral da Constituição norte-americana. São Paulo: M. Fontes, 2006. p. 26.
} 
concepção constitucional, porque qualquer objeção ao judicial review deve demonstrar que as leis em questão respeitam as condições democráticas para terem legitimidade. ${ }^{89}$

A concepção de democracia em Dworkin é mais sofisticada que a majoritária, porque não é estatística. ${ }^{90}$ É incoerente sustentar a absolutização do princípio majoritário, confundindo-o com a democracia. Diz Dworkin: "A autodeterminação é a idéia política mais poderosa - e perigosa - da nossa época”.91 Como é observável, Dworkin defende uma democracia substancial e não formal. ${ }^{92} \mathrm{Da}$ mesma forma, Vieira ${ }^{93}$ sustenta que a regra da maioria não é a democracia, sob pena de confundi-la com o absolutismo da maioria. ${ }^{94}$

Não se admite um Judiciário atido somente aos checks and balances, pois a jurisdição constitucional deve ser contramajoritária. ${ }^{95}$ Dando ênfase a essa discussão, diz Streck:

O problema é que o Judiciário sempre se encontra diante de um dilema: se assume postura intervencionista, imiscuindose até mesmo no controle de políticas públicas ou de instalação de CPIs, é acusado de ativista (quando não, de utilizar a jurisprudência dos valores); se assume uma postura self restrainting, (veja-se o caso do mandado de injunção e a discussão sobre a cassação de liminares durante a "grande

${ }^{89}$ DWORKIN, Ronald . O direito da liberdade: a leitura moral da Constituição norte-americana. São Paulo: M. Fontes, 2006. p. 27.

${ }^{90}$ DWORKIN, Ronald . O direito da liberdade: a leitura moral da Constituição norte-americana. São Paulo: M. Fontes, 2006. p. 30.

${ }^{91}$ DWORKIN, Ronald . O direito da liberdade: a leitura moral da Constituição norte-americana. São Paulo: M. Fontes, 2006. p. 33.

${ }^{92}$ A respeito da diferenciação entre democracia formal e substancial, cf. MORAIS, José Luis Bolzan de; AGRA, Walber de Moura. A jurisprudencialização da Constituição e a densificação da legitimidade da jurisdição constitucional. Revista do Instituto de Hermenêutica Jurídica: (Neo) Constitucionalismo: ontem, os códigos, hoje as constituições, Porto Alegre, v. 1, n. 2, 2004.

${ }_{93}$ VIEIRA, Renato Stanziola. Jurisdição constitucional e os limites de sua legitimidade democrática. Rio de Janeiro: Renovar, 2008. p. 15.

${ }^{94}$ Uma das maneiras de definir democracia, segundo Sartori, é dizer o que ela não é, já que seus rumos são incertos e ela não é um conceito unívoco, mas antes um debate. A respeito, cf. SARTORI, Giovanni. A teoria de democracia revisitada. São Paulo: Ática, 1994. p. 24.

${ }^{95}$ STRECK, Lenio Luiz; MORAIS, José Luis Bolzan de. Jurisdição constitucional e hermenêutica. 2. ed. Rio de Janeiro: Forense, 2004. p. 180. 
privatização" ocorrida no governo Fernando Henrique), é criticado pela sua timidez ou conservadorismo. ${ }^{96}$

Segundo Cappelletti, ${ }^{97}$ o problema não é se os juízes criam o Direito, pois esse é apenas o ponto de partida. A questão não resolvida cinge-se aos modos, limites e legitimidade da criação jurisprudencial. É evidente que a legitimidade da jurisdição é tema complexo, de tal monta que Dworkin hipostasiou um modelo de juiz, Hércules, de força e capacidade sobre-humana. Ele é um exemplo a ser seguido, pois busca compreender a tradição em que estamos inseridos. ${ }^{98}$

O direito como integridade pressupõe que o juiz assuma a sua função constitucional em plenitude, ou seja, efetivamente busque ou tente ser o mais próximo possível de um “juiz Hércules”, um juiz imaginário, de capacidade e paciência sobre-humanas, que aceita o direito como integridade e que tenha um longo tempo de reflexão acerca das causas que deve julgar, ponderando todas as variáveis possíveis para a decisão. ${ }^{99}$

Tal juiz deverá estar impregnado de uma "moral pública ou política”. O direito como integridade exige o comprometimento ético do magistrado para com os princípios políticos importantes para a comunidade, que devem ser levados em conta para o julgamento. $\mathrm{O}$ direito como integridade exige que os juízes admitam que o direito é estruturado por um conjunto de princípios sobre a justiça, a equidade e o devido processo legal, ${ }^{100}$ e que suas concepções de moralidade pública devem estar fundadas nesses princípios. Na era do pós-positivismo, os princípios passam a ser tratados como direito, afirma Paulo Bonavides: ${ }^{101}$

\footnotetext{
${ }^{96}$ STRECK, Lenio Luiz; MORAIS, José Luis Bolzan de. Verdade e consenso. Rio de Janeiro: Luhmen Júris, 2008. p. 145 e 151. Segundo o autor, a aferição da fronteira entre o que é ou não é ativismo judicial tem sido polêmica, porque ainda presa à tarefa exclusiva de um sujeito cognoscente.

${ }^{97}$ CAPPELLETTI, Mauro. Juízes legisladores. Porto Alegre: S. A. Fabris Editor, 1999. p. 25.

${ }^{98}$ SAAVEDRA, Giovani Agostini. Jurisdição e democracia: uma análise a partir das teorias de Jurgen Habermas, Robert Alexy, Ronald Dworkin e Niklas Luhman. Porto Alegre: Livraria do Advogado, 2006. p. 83.

${ }^{99}$ DWORKIN, Ronald. O império do direito. São Paulo: M. Fontes, 1999. p. 287.

${ }^{100}$ DWORKIN, Ronald. O império do direito. São Paulo: M. Fontes, 1999. p. 291.

${ }^{101}$ BONAVIDES, Paulo. Curso de direito constitucional. 19. ed. São Paulo: Malheiros, 2006. p. 265.
} 
É na idade do pós-positivismo que tanto a doutrina do Direito Natural como a do velho positivismo ortodoxo vêm abaixo, sofrendo golpes profundos e crítica lacerante, provenientes de uma reação intelectual implacável, capitaneada sobretudo por Dworkin, jurista de Harvard. Sua obra tem valiosamente contribuído para traçar e caracterizar o ângulo novo de normatividade definitiva reconhecida aos princípios.

Uma das principais críticas de Waldron a Dworkin consiste na "doutrina da sabedoria da multidão", retomada de uma passagem de Aristóteles, em que o estagirita reconhece que ela pode ser verdadeira. Segundo a DSM, o povo atuando conjuntamente é sempre melhor do que um único homem, por melhor que ele seja, pois a reunião das qualidades de diversos homens não é encontrável em um único homem, por mais excelência que ele possa ter. ${ }^{102} \mathrm{Ou}$ seja, Waldron enuncia uma tese de reforço ao princípio majoritário e critica que alguns juízes, por mais excelentes que eles possam ser, possam ser melhores do que a multidão, e, nessa hipótese, o Parlamento. Ele ainda alega que Kant era um positivista, pois dizia que havia um dever absoluto de obediência à legislação, ${ }^{103}$ pois mesmo que se discorde do que foi deliberado, deve-se respeitar o fato de compartilharmos de uma ideia de justiça, por mais equívoca que seja. ${ }^{104}$ Outra crítica de Waldron, que pode ser dirigida a Dworkin, é que não há razão para negar que os tribunais não sejam órgãos majoritários ${ }^{105}$ e não possam errar. Mas é importante considerar que Dworkin

${ }^{102}$ WALDRON, Jeremy. A dignidade da legislação. São Paulo: M. Fontes, 2003, p. 113.

${ }^{103}$ WALDRON, Jeremy. A dignidade da legislação. São Paulo: M. Fontes, 2003, p. 73.

${ }^{104} \mathrm{~A}$ respeito, cf. também o livro de MELLO, Cláudio Ari. Kant e a dignidade da legislação. Porto Alegre: Livraria do Advogado, 2009. p. 32 et seq. Uma das razões de Waldron ter escrito The Dignity of Legislation foi sua insatisfação com a proeminência do Poder Judiciário e o descrédito do Poder Legislativo. Como positivista, Waldron critica os sistemas jurídicos que permitem que o Judiciário fiscalize a constitucionalidade de leis elaboradas pelos legisladores. Portanto, subjacente à sua discussão está a crítica ao judicial review. Waldron não vê o desacordo político como algo ruim, mas até mesmo como um avanço, porque denuncia os limites da política e já pressupõe o debate, ou seja, há um consenso de que não há acordo, o que já é um passo. Fundamentalmente, ele diz que não há por que considerar os juízes responsáveis perante a comunidade, pois o processo judicial não pode abarcar o pluralismo político na sua totalidade e não empresta valor ao desacordo razoável. Ele quer demonstrar que há argumentos de princípio que dão proeminência ao Legislativo sobre o Judiciário a partir da tradição filosófica.

${ }^{105}$ MELLO, Cláudio Ari. Kant e a dignidade da legislação. Porto Alegre: Livraria do Advogado, 2009. p. 156. 
nunca disse que o ativismo judicial não traz riscos e nem que os juízes não possam falhar, pois são homens e não semideuses como Hércules. Ele defendeu a jurisdição constitucional como um meio legitimamente democrático para controlar as decisões da maioria, mas nunca deixou de denunciar os problemas hermenêuticos da jurisdição, especialmente a discricionariedade. Em suma, ele confia na jurisdição, trazendo argumentos de reforço a isso, mesmo que saiba dos inconvenientes hermenêuticos da possibilidade de decisionismo judicial.

\section{Considerações finais}

O presente trabalho buscou trazer elementos de discussão acerca da jurisdição constitucional, especialmente a judicialização da política e o ativismo judicial à luz da democracia constitucional. Como foi ressaltado, é possível trazer elementos de legitimação democrática à atuação do Poder Judiciário, a partir da noção de contramajoritarismo e de garantia dos direitos fundamentais. Dworkin efetivamente possibilita uma crítica aos argumentos contrários à intervenção do Judiciário na vida política.

Ele não deixa de considerar os riscos da discricionariedade judicial, mas defende argumentos de princípio, que são filosóficos, a partir dos quais a concepção majoritária de democracia é equivocada, porque não protege os direitos assegurados contra ataques da maioria. Além disso, em Dworkin a democracia é qualitativa e não quantitativa, o que significa que mesmo uma maioria eventual pode ser antidemocrática, se contrariar a Constituição. Ou seja, Dworkin resgata a igualdade na noção de democracia, dizendo que o primado da igualdade é o que importa. Ele reforça uma concepção substancialista de democracia, em que o que importa não é somente a deliberação representativa, mas o asseguramento dos direitos substantivos garantidos no direito constitucional. Não há sustentação em taxar o judicial review como um instituto antidemocrático, pois se pode argumentar que a deliberação majoritária muitas vezes viola a democracia ao impor convicções que agridem a moralidade pública ou política dos indivíduos, ou que ferem os princípios constitucionais. 
A judicialização da política e das relações sociais e o ativismo judicial são fenômenos distintos, se bem que imbricados. A possibilidade do ativismo judicial somente teve guarida a partir do fenômeno da judicialização, pois o agigantamento do Judiciário no século. XX significou que este não está mais refém da vontade política do legislador. Ao contrário, o Judiciário deve atuar contra as deliberações majoritárias se elas forem ilegítimas ou inconstitucionais, manifestando, entretanto, a sua accountability por meio da fundamentação das suas decisões.

A democracia contemporânea transferiu grande parte da responsabilidade pela sua manutenção aos juízes, na medida em que a judicialização fez com que a magistratura passasse a lidar com temas políticos que sempre foram estranhos ao Judiciário, tido como órgão burocrático. A judicialização da política e das relações sociais representa o surgimento de um novo Judiciário, mais responsável socialmente e politicamente inserido nos debates político-constitucionais acerca das políticas públicas.

No que tange ao ativismo judicial, fica claro que é descabido discuti-lo in abstrato, criticando-o ou elogiando-o de forma descontextualizada. A crítica ao ativismo judicial é sempre relacionada à deliberação política dos juízes em certas circunstâncias de tempo e lugar, ficando claro que existem por detrás das críticas sempre interesses e ideologias. Assim, conservadores e progressistas divergirão sobre os benefícios do ativismo judicial, porquanto comungam diferentes concepções de mundo.

É importante destacar que a democracia contemporânea cada vez mais se desloca dos foros dos parlamentos para os tribunais, das bancadas para as togas. Isso não implica em dizer que os juízes substituíram os eleitos pelo povo. $\mathrm{O}$ que isso significa é que, em uma época de profunda crise de representatividade, e considerando que não há democracia sem garantia de direitos, cada vez mais o asseguramento das garantias constitucionais depende da postura do Poder Judiciário, e a posição self restraint afigura-se, muitas vezes, inadequada para lidar com as novas necessidades sociais de concretização de direitos, pelo menos em hipóteses de omissões inconstitucionais e declaração de inconstitucionalidade de leis. Posturas ativistas, entendidas aqui como remédios à ineficácia de direitos, não são an- 
tidemocráticas; ao contrário, resta questionar: existiria democracia sem garantias contramajoritárias? A partir da democracia constitucional de Dworkin, a resposta é negativa, porque, sem a tutela da igualdade, a democracia inexiste.

\section{The Democratic Legitimacy of constitucional jurisdiction and the countermajoritarism in the context of the judicialization of politics and judicial activism}

\section{Abstract}

This paper discusses the democratic legitimacy of the constitutional jurisdiction which against majority, considering as a paradigm Dworkin's thought regarding constitutional democracy. It seeks to tackle issues such as judicialization of politics and judicial activism regarding the intervention of the judicial power in the political arena, bringing arguments which are for and against its performance. To do so, this research questions the limits and possibilities of the constitutional jurisdiction, including jurisdiction which is against majority and the respect for fundamental rights. As approach methods, the inductive and deductive methods will be used. As procedure methods, the historical and monographic ones will be employed. Besides, as research techniques, we'll apply direct documentation, that is, jurisprudence, and indirect documentation based on the law literature.

Keywords: Democratic legitimacy. Constitutional jurisdiction. Judicialization of politics. Judicial activism.

\section{Referências}

ALSTYNE, William Van. Judicial activism and judicial restraint. In: LEVY, Leonard W; KARST, Kenneth L; MAHONEY, Dennis (Org.). Judicial power and the Constitution. New York: Macmillan Publishing Company, 1990. p. 58-72.

BARROSO, Luís Roberto. Judicialização, ativismo judicial e legitimidade democrática. Revista Direito do Estado, Salvador, ano 4, n. 13, p. 71-91, jan./mar 2009. 
BIGNOTTO, Newton. Soberania e exceção no pensamento de Carl Schmitt. Kriterion, Belo Horizonte, n. 118, dez./2008, p. 401- 415.

BOCKENFORDE, Ernst-Wolfang. The concept of the political: a key to understanding Carl Schmitt's Constitucional Theory. In: DYZENHAUS, David (Org.). Law as politics: Carl Schmitt critique of liberalism. Durham: Duke University Press, 1998.

BONAVIDES, Paulo. Curso de direito constitucional. 19. ed. São Paulo: Malheiros, 2006.

BRASIL. Supremo Tribunal Federal. Ação Direta de Inconstitucionalidade n. 3.999. Partido Social Cristão e Tribunal Superior Eleitoral. Relator: Joaquim Barbosa. 12 de novembro de 2008. Disponível em: < http://www.stf.jus.br/portal/inteiroTeor/ pesquisarInteiroTeor.asp\#resultado>. Acesso em: 26 dez. 2009.

BRASIL. Supremo Tribunal Federal. Mandado de Injunção n. 670. Sindicato dos Servidores Policiais Civis e Congresso Nacional. Relator: Min. Gilmar Mendes. 25 de Outubro de 2007. Disponível em: < http://www.stf.jus.br/portal/inteiroTeor/ pesquisarInteiroTeor.asp\#resultado>. Acesso em: $26 \mathrm{dez} .2009$.

BRASIL. Tribunal Superior Eleitoral. Resolução n. 22.610/07. Relator: Min. Cezar Peluso. Disponível em: <http://www.tse.gov.br/internet/ jurisprudencia/index. htm>. Acesso em: 26 dez. 2009.

CANOTILHO, José Joaquim Gomes. Direito constitucional e teoria da Constituição. 4. ed. Coimbra: Almedina, 1998.

CAPPELLETTI, Mauro. Juízes legisladores. Porto Alegre: S. A. Fabris Editor, 1999.

CAPPELlETTI, Mauro; GARTH, Bryant. Acesso à justiça. Porto Alegre: S. A. Fabris Editor, 1988.

CARVAlHO, Carlos Araújo de. Ativismo judicial em crise. Disponível em: < http://jus2.uol.com.br/doutrina/texto.asp?id=12781>. Acesso em: 23 dez. 2009.

CARVALHO, Ernani Rodrigues de. Judicialização da política no Brasil: controle de constitucionalidade e racionalidade política. Análise Social, v. 191, p. 315-335. 2009.

CARVALHO, Ernani Rodrigues de. Em busca da judicialização da política no Brasil: apontamentos para uma nova abordagem. Revista de Sociologia Política, Curitiba, n. 23, p. 115-126, nov. 2004. 
CITTADINO, Gisele. Pluralismo, direito e justiça distributiva. 4. ed. Rio de Janeiro: Luhmen Júris, 2009.

CITTADINO, Gisele. Poder Judiciário, ativismo judiciário e democracia. Alceu, Rio de Janeiro, v. 5, n. 9, p. 105-113. jul./dez. 2004.

DAVID, René. Os grandes sistemas do direito contemporâneo. São Paulo: M. Fontes, 2000. p. 433.

DINIZ, Antônio Carlos. Legitimidade. In: BARRETO, Vicente de Paulo (Coord.). Dicionário de Filosofia do Direito. São Leopoldo: Editora Unisinos; Rio de Janeiro: Editora Renovar: 2006. p. 514-517.

DWORKIN, Ronald . O direito da liberdade: a leitura moral da Constituição norteamericana. São Paulo: M. Fontes, 2006.

DWORKIN, Ronald. Levando os direitos a sério. São Paulo: M. Fontes, 2002.

DWORKIN, Ronald. O império do direito. São Paulo: M. Fontes, 1999.

DWORKIN, Ronald. Uma questão de princípios. São Paulo: M. Fontes, 2001.

FAVOREU, Louis. As cortes constitucionais. São Paulo: Landy Editora, 2004.

GIACOMUZZI, José Guilherme. As raízes do realismo americano: breve esboço acerca de dicotomias, ideologia e pureza no direito dos USA. Revista de Direito Administrativo, Rio de Janeiro, n. 239, p. 359-388, jan./mar. 2005.

GILISSEN, John. Introdução histórica ao direito. 4. ed. Lisboa: Fundação Calouste Gulbenkian, 2003.

HEGEL, Georg Friedrich Wilhelm. Princípios da filosofia do direito. São Paulo: Martins Fontes, 1997.

KELSEN, Hans. Jurisdição constitucional. São Paulo: Martins Fontes, 2003.

LAGO, Rodrigo Pires Ferreira. O Supremo constituinte: uma visão crítica do ativismo judicial do Supremo Tribunal Federal. Jus Navigandi, Teresina, ano. 14, n. 2319, 6 nov. 2009. Disponível em: <http://jus2.uol.com.br/ doutrina/texto. asp?id=13805>. Acesso em: 22 dez. 2009. 
LUCAS, Doglas Cesar. A crise funcional do Estado e o cenário da jurisdição desafiada. In: MORAIS, José Luis Bolzan de (Org.). O Estado e suas crises. Porto Alegre: Livraria do Advogado, 2005.

MACIEL, Débora; KOERNER, Andrei. Sentidos da judicialização da política: duas análises. In: Lua Nova. 2002, n. 57, p. 113-133. Disponível em: < http://www.scielo. br/pdf/ln/n57/a06n57.pdf > Acesso em: 16 nov. 2009.

MELLO, Cláudio Ari. Kant e a dignidade da legislação. Porto Alegre: Livraria do Advogado, 2009.

MORAES, Alexandre de. Direito constitucional. 23. ed. São Paulo: Atlas, 2008.

MORAIS, José Luis Bolzan de; AGRA, Walber de Moura. A jurisprudencialização da Constituição e a densificação da legitimidade da jurisdição constitucional. Revista do Instituto de Hermenêutica Jurídica: (Neo) Constitucionalismo: ontem, os códigos, hoje as constituições, Porto Alegre, v. 1, n. 2, p. 217-242, 2004.

OHLWEILER, Leonel Pires. O contributo da jurisdição constitucional para a formação do regime jurídico administrativo: Revista do Instituto de Hermenêutica Jurídica: (Neo) Constitucionalismo: ontem os códigos, hoje as constituições, Porto Alegre, v.1, n. 2, p. 285-328, 2004.

OLIVEIRA, Cláudio Ladeira de. Ativismo judicial, autorestrição judicial e o "minimalismo" de Cass Sustein. Disponível em: < http://www.diritto.it/ archivio/1/27004.pdf $>$. Acesso em: 22 dez.2009.

OLIVEIRA, Cláudio Ladeira de. Direito como integridade e ativismo judicial: algumas considerações acerca de uma decisão do Supremo Tribunal Federal. Disponível em: <http://www.buscalegis.ufsc.br /revistas/index. php/buscalegis/ article/viewFile/33059/32237> Acesso em: 28 out. 2010.

ROCHA, Leonel Severo. Epistemologia jurídica e democracia. 2.ed. São Leopoldo: Ed. Unisinos, 2005.

SAAVEDRA, Giovani Agostini. Jurisdição e democracia: uma análise a partir das teorias de Jurgen Habermas, Robert Alexy, Ronald Dworkin e Niklas Luhman. Porto Alegre: Livraria do Advogado, 2006.

SARLET, Ingo. A eficácia dos direitos fundamentais. 2. ed. Porto Alegre: Livraria do Advogado, 2001. 
SARLET, Ingo. Contornos do direito fundamental à saúde na Constituição Federal de 1988. Revista da Procuradoria-Geral do Estado do Rio Grande do Sul. Porto Alegre: v. 25, n. 56, dez. 2002.

SARLET, Ingo. Dignidade da pessoa humana e direitos fundamentais. 3. ed. Porto Alegre: Livraria do Advogado, 2004.

SARTORI, Giovanni. A teoria de democracia revisitada. São Paulo: Ática, 1994.

SCHMITT, Carl. O guardião da Constituição. Belo Horizonte: Del Rey, 2007.

STRECK, Lenio Luiz. Hermenêutica. In: BARRETO, Vicente de Paulo (Coord.) Dicionário de Filosofia do Direito. São Leopoldo: Editora Unisinos; Rio de Janeiro: Editora Renovar: 2006, p. 430-434.

STRECK, Lenio Luiz; MORAIS, José Luis Bolzan de. Ativismo judicial não é bom para a democracia. Disponível em: <http://leniostreck.com.br/index. php?option $=$ com_content\&task $=$ view\&id $=87 \&$ Itemid $=1>$. Acesso em: $22 \mathrm{dez}$. 2009.

STRECK, Lenio Luiz; MORAIS, José Luis Bolzan de. Ciência política e teoria geral do Estado. 4. ed. Porto Alegre: Livraria do Advogado, 2004.

STRECK, Lenio Luiz; MORAIS, José Luis Bolzan de. Jurisdição constitucional e hermenêutica. 2. ed. Rio de Janeiro: Forense, 2004.

STRECK, Lenio Luiz; MORAIS, José Luis Bolzan de. OAB in foc, Uberlandia, ano 4, n. 20, p. 15, ago./set., 2009.

STRECK, Lenio Luiz; MORAIS, José Luis Bolzan de. Verdade e consenso. Rio de Janeiro: Luhmen Júris, 2008.

TAVARES, Rodrigo de Souza et al. Ativismo jurisdicional e o Supremo Tribunal Federal. In: CONGRESSO NACIONAL DO CONPEDI, 17, 2008, Brasília. Anais... Brasília, 2008.

VALLINDER, T; TATE, C. Neal. The global expansion of judicial power: the judicialization of politics. New York: New York University, 1995.

VIANNA, Luiz Werneck et al. A judicialização da política e das relações sociais no Brasil. Rio de Janeiro: Revan, 1999. 
Prismas: Dir., Pol. Publ. e Mundial., Brasília, v. 8, n. 1, p. 1-43, jan./jun. 2011 A legitimidade democrática da jurisdição constitucional e o contramajoritarismo...

VIEIRA, Renato Stanziola. Jurisdição constitucional e os limites de sua legitimidade democrática. Rio de Janeiro: Renovar, 2008.

WALDRON, Jeremy. A dignidade da legislação. São Paulo: M. Fontes, 2003. 


\section{Para publicar na revista Prismas: Direito, Políticas}

Públicas e Mundialização, acesse o endereço eletrônico www.publicacoesacademicas.uniceub.br. Observe as normas de publicação, para facilitar e agilizar o trabalho de edição. 